\title{
Laboratory Directed Research \& Development Program Assessment For FY 2007
}

\section{Annual Report}

\author{
BROOKHAVEN NATIONAL LABORATORY \\ BROOKHAVEN SCIENCE ASSOCIATES \\ UPTON, NEW YORK 11973-5000 \\ UNDER CONTRACT NO. DE-AC02-98CH10886 \\ UNITED STATES DEPARTMENT OF ENERGY
}

December 2007 


\section{Table of Contents}

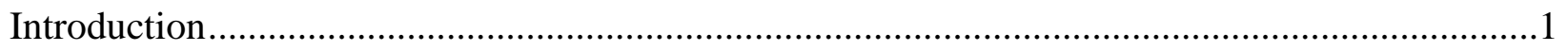

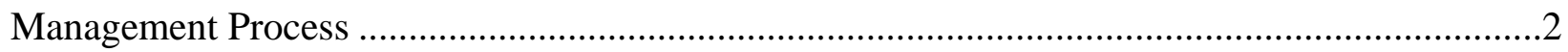

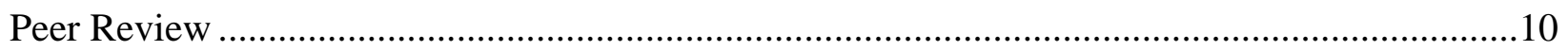

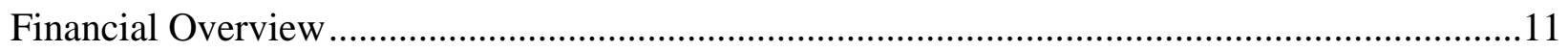

Relatedness of LDRD to Laboratory Programs and Initiatives ....................................................13



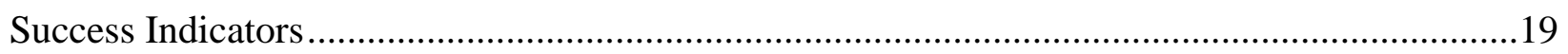

Appendix A - Funding Table of LDRD Projects Approved FY 2007 ....................................... A-1

Exhibit A - Call for Proposals for FY 2008 ...............................................................................

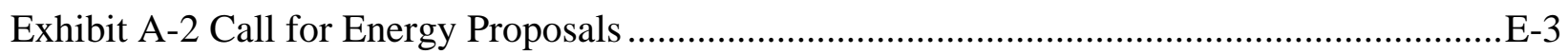

Exhibit B - Proposal Information Questionnaire (PIQ) ...........................................................

Exhibit B-2 Energy Proposal Information Questionnaire...............................................................

Exhibit C - Data Collection Form ............................................................................................. E-19

Exhibit D - Instructions for LDRD Selection Committee.........................................................

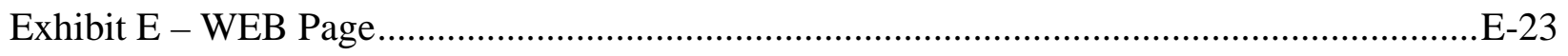

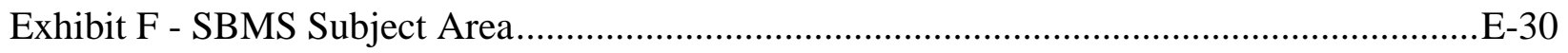

Exhibit G - Monday Memo Article .......................................................................................

Exhibit H - FY 2008 LDRD New Starts ...............................................................................35

Exhibit I - Relatedness to Laboratory Initiatives by Project...........................................................-39

Exhibit J - R. Orbach Increases FY 2007 Ceiling ..................................................................... 


\section{Introduction}

Brookhaven National Laboratory (BNL) is a multidisciplinary laboratory that carries out basic and applied research in the physical, biomedical, and environmental sciences, and in selected energy technologies. It is managed by Brookhaven Science Associates, LLC, (BSA) under contract with the U. S. Department of Energy (DOE). BNL's Fiscal Year 2007 spending was \$515 million. There are approximately 2,600 employees, and another 4,500 guest scientists and students who come each year to use the Laboratory's facilities and work with the staff.

The BNL Laboratory Directed Research and Development (LDRD) Program reports its status to the U.S. Department of Energy (DOE) annually in March, as required by DOE Order 413.2B, "Laboratory Directed Research and Development," April 19, 2006, and the Roles, Responsibilities, and Guidelines for Laboratory Directed Research and Development at the Department of Energy/National Nuclear Security Administration Laboratories dated June 13, 2006.

The goals and objectives of BNL's LDRD Program can be inferred from the Program's stated purposes. These are to (1) encourage and support the development of new ideas and technology, (2) promote the early exploration and exploitation of creative and innovative concepts, and (3) develop new "fundable" R\&D projects and programs. The emphasis is clearly articulated by BNL to be on supporting exploratory research "which could lead to new programs, projects, and directions" for the Laboratory.

As one of the premier scientific laboratories of the DOE, BNL must continuously foster groundbreaking scientific research. At Brookhaven National Laboratory one such method is through its LDRD Program. This discretionary research and development tool is critical in maintaining the scientific excellence and long-term vitality of the Laboratory. Additionally, it is a means to stimulate the scientific community and foster new science and technology ideas, which becomes a major factor in achieving and maintaining staff excellence and a means to address national needs within the overall mission of the DOE and BNL.

The LDRD Program Assessment Report contains a review of the program. The report includes a summary of the management processes, project peer review, and the portfolio's relatedness to BNL's mission, initiatives and strategic plans. Also included are a metric of success indicators and Self Assessment. 


\section{Management Process}

\section{PROGRAM ADMINISTRATION:}

Overall Coordination:

Overall responsibility for coordination, oversight, and administration of BNL's LDRD Program resides with the Laboratory's Director. Day-to-day responsibilities regarding funding, oversight, proposal evaluation, and report preparation have been delegated to the dedicated Scientific Director (SD) for the LDRD Program who reports to the Assistant Laboratory Director for Policy and Strategic Planning (PSP). The Office of the Assistant Laboratory Director for Finance (ALDF) assists in the administration of the program. This includes administering the program budget, establishing project accounts, maintaining summary reports, and providing reports of Program activities to the DOE through the Brookhaven Site Office Manager.

At BNL, the DOE approved LDRD Program budget has been significantly increased over the past ten years from $\$ 2.0$ million to $\$ 15.5$ million. This allows the Laboratory to prepare itself for work in emerging areas of research.

Program Structure:

The program consists of two categories of projects, Competed LDRDs and Strategic LDRDs (S-LDRD), which when combined, meet the overall objectives of the LDRD Program.

Competed LDRDs - Proposals are solicited annually for review and approval concurrent with the next fiscal year, October 1. An LDRD Selection Committee, comprised of the Associate Laboratory Directors (ALD) for the Scientific Directorates, an equal number of scientists recommended by the Brookhaven Council, plus the LDRD Scientific Director, and the Assistant Laboratory Director for Policy and Planning, review the proposals submitted in response to the solicitation.

The competed LDRD category emphasizes innovative research concepts with limited management filtering to encourage the creativity of individual researchers. The competition is open to all BNL staff in programmatic, scientific, engineering, and technical support areas. Researchers submit their project proposals through their respective chairperson and ALD to the LDRD Scientific Director.

Strategic LDRDs - A portion of the LDRD budget is held for the Strategic LDRD (S-LDRD) category. These funds are used to establish and enhance initiatives that are consistent with Laboratory priorities. Projects in this category focus on innovative R\&D activities that are likely to develop new programmatic areas within BNL's mission responsibilities and enhance the Laboratory's science and technology base. The Laboratory Director entertains requests or articulates the need for S-LDRD funds at any time. 
These Projects are driven by special opportunities, including

- $\quad$ Research project(s) in support of a laboratory strategic hire,

- Evolution of Program Development activities into research and development activities,

- ALD proposal(s) to the Director to support unique research opportunities,

- $\quad$ Research project(s) in support of laboratory strategic initiatives as defined and articulated by the Director.

In addition for Fiscal Year 2008 the Laboratory formulated an Energy Strategy whereby working groups were established to delineate plans for areas of interest. Proposals were solicited in support of this strategy.

Allocating Funds:

There are several decisions to be made each year concerning the allocation of funds for the LDRD Program.

These are: (1) the amount of money that should be budgeted overall for the Program; (2) the amount to be allocated between the two categories, and (3) how much, should go to each competing project or proposal. All of these decisions are made by senior-level management.

For each upcoming fiscal year the Laboratory Director, on recommendation by the Deputy Director for Science and Technology (DDS\&T), the Assistant Laboratory Director for Policy and Strategic Planning (PSP) and the LDRD Scientific Director (SD) and in consultation with the ALDF, develops an overall level of funding for the LDRD Program. The budgeted amount is incorporated into the Laboratory's LDRD Plan, which formally requests authorization from the DOE to expend funds for the LDRD Program up to this ceiling amount.

Generally, projects are authorized for funding at the start of the fiscal year. In addition, projects can be authorized throughout the fiscal year, as long as funds are available and the approved ceiling for the LDRD Program is not exceeded.

The actual level expended, which may be less than budgeted, is determined during the course of the year and is affected by several considerations including: the specific merits of the various project proposals, as determined by Laboratory management and the members of the LDRD Program Committee; the overall financial health of the Laboratory; and a number of budgetary tradeoffs between LDRD and other overhead expenses.

Competed LDRD Selection Process:

Responsibility for the allocation of resources and the review and selection of proposals lies with a management-level group called the Laboratory Directed Research \& Development Program Committee. For Fiscal Year 2007, the Program Committee, which selected the new 2008 programs, consisted of eleven members. The SD chaired the Committee, and the other members were the Assistant Laboratory Director for Policy and Strategic Planning (PSP), five Associate Laboratory Directors (ALDs), and five members of the Brookhaven Council (BC). 


\begin{tabular}{|c|c|}
\hline Leonard Newman & Chairperson (SD) \\
\hline J. Patrick Looney & $\begin{array}{l}\text { Assistant Laboratory Director for Policy and } \\
\text { Strategic Planning (PSP) }\end{array}$ \\
\hline Ralph James & $\begin{array}{l}\text { Energy, Environment \& National Security } \\
\text { (ALD) }\end{array}$ \\
\hline Steven Vigdor & Nuclear \& Particle Physics (ALD) \\
\hline Steven Dierker & Light Sources (ALD) \\
\hline James Misewich & Basic Energy Sciences (Interim ALD) \\
\hline Fritz Henn & Life Sciences (ALD) \\
\hline Dmitri Kharzeev & Physics (BC) \\
\hline Lawrence Kleinman & Environmental Sciences (BC) \\
\hline Jean Logan & Medical (BC) \\
\hline G. L. Carr & Light Source (BC) \\
\hline Trevor Sears & Chemistry (BC) \\
\hline
\end{tabular}

Request for Proposals:

The availability of special funds for research under the LDRD Program is well publicized throughout the Laboratory. This is done using two methods -- one occurring at yearly intervals, the other occurring irregularly. Each year a call letter is sent out by the SD for LDRD to the Scientific Staff and as a separate memorandum to all the Associate Laboratory Directors and Department Chairpersons. The FY 2008 call memoranda, issued in March 2007 are attached as Exhibit A.

The call references the BNL LDRD Standards-Based Management System (SBMS) Subject Area, which is available to all employees on the web and is attached as Exhibit F. The other method is through a feature article in The Bulletin or Monday Memo. The FY 2008 announcement was issued in the April 9, 2007 Monday Memo, see Exhibit G. The process that solicits and encourages the development of proposals also identifies the current Laboratory Strategic Focus Area, which are of special interest to Laboratory management. In this connection a separate call for energy related proposals was issued on June 14, 2007, see Exhibit A-2. In this call longer proposals and external reviews were required. These are detailed in the side bar on the LDRD web page, see Exhibit E.

The LDRD SBMS Subject Area specifies the requirements necessary for participation in the program. It states the program's purpose, general characteristics, procedures for applying, and restrictions. An application for funding, i.e., a project proposal, takes the form of a completed "Proposal Information Questionnaire (PIQ)," Exhibit B. An application must be approved through the appropriate management levels, which includes the initiator's Department or Division Budget Administrator and the Department Chairperson or Division Head.

The Chairperson or Division Head reviews the Proposal Information Questionnaire for completeness, which includes the review of responses to questions on National Environmental Policy Act (NEPA) and Environmental Safety and Health (ES\&H). He/she also ensures that the principal investigator's regularly funded programs are not impacted by the LDRD project. 
The applications are then forwarded to the LDRD Program Committee for full review and consideration for funding.

Proposal Review:

Once the cognizant line managers approve the proposals, they are forwarded to the Chairperson of the Committee (SD for LDRD) who transmits a copy of the abstracts of all proposals received to the Committee for review. The Committee considers all proposals that have met certain minimum requirements pertaining to the Department's and BNL's LDRD policies.

Lead proponent responsibility of a proposal is assigned to that Associate Laboratory Director of the Committee who oversees and directs the technical area from which the proposal originated. One other ALD and an BC serve as second proponents. The PSP serve as a third proponent for all of the proposals. All of the above receive for review, the full proposals for which they are responsible.

A description of the process is outlined in the Figure on the next page. See Exhibit D for the instructions to the LDRD Selection Committee. All members have several weeks to review the proposals and prepare for a full debate on each proposal. The DOE Project Manager is present during the Committee evaluation sessions as a non-voting member

\section{Selection Criteria:}

Minimum requirements for each proposal are: (1) consistency with program purpose; (2) consistency with missions of BNL, DOE, and NRC; (3) approval by Department Chairperson and/or Division Head, and cognizant Associate/Assistant Director; (4) assurance of satisfactory continuation of principal investigator's regularly funded programs; (5) modest size and generally scheduled for 2 years but limited to no more than 3 years; (6) will not substitute for, supplement, or extend funding for tasks normally funded by DOE/NNSA; (7) will not create a commitment of future multi-year funding to reach a useful stage of completion; and (8) will not fund construction of lineitem projects, facility maintenance, or general purpose capital equipment.

The selection criteria used to evaluate and rank individual proposals are stated in broad terms. While the LDRD SBMS Subject Area clearly states that selection is based on (1) scientific or technological merit, (2) innovativeness, (3) compliance with minimum requirements, (4) proposal cost as compared to the amount of available funding, and (5) its potential for follow-on funding. The requirements of DOE Order 413.2B are also carefully considered during the selection process to ensure that proposals are consistent with DOE criteria. 
Competed LDRD Projects Program Process




Project Selection:

All proposals are rated by the full Committee and then discussed with the discussion of the lower rated proposals kept to a minimum. The Committee selects the highest priority proposals, by concurrence, for detailed discussion. Final selections are made by a vote of the ALDs as recommended for funding. Some funding may be held in reserve earlier in the fiscal year so that funds remain available for proposals submitted at later dates. The funding amount requested in any one specific proposal may be changed or adjusted during the approval process. The Committee's recommendation is then submitted to the Laboratory Director for approval. After approval by the Director all new projects are submitted to the DOE-Brookhaven Site Office (DOE-BHSO) for concurrence by the DOE Project Manager prior to start. The ALDF then sets up a separate laboratory overhead account to budget and collect the costs for the project.

Strategic LDRDs Selection Process:

Responsibility for the allocation of resources and the review and selection of proposals lies with the Assistant Laboratory Director for Policy and Strategic Planning, Deputy Director for Science and Technology and the Laboratory Director.

Request for Proposals:

The availability of special funds for research under the Strategic LDRD Program is disseminated by the Laboratory Director to the Associate Laboratory Directors.

The LDRD SBMS Subject Area specifies the requirements necessary for participation in the program. It states the program's purpose, general characteristics, procedures for applying, and restrictions. An application for funding, i.e., a project proposal, takes the form of a completed "Proposal Information Questionnaire (PIQ)", Exhibit B. An application must be approved through the appropriate management levels, which includes the initiator's Department or Division Budget Administrator and the Department Chairperson or Division Head.

The Chairperson or Division Head reviews the PIQ for completeness. This includes the review of responses to questions on National Environmental Policy Act (NEPA) and Environmental Safety and Health (ES\&H).

The applications are then forwarded to the LDRD Scientific Director for full review and consideration for funding.

Proposal Review:

Once the cognizant line managers approve the proposals, they are forwarded to the LDRD Scientific Director. The LDRD Scientific Director examines the proposal for compliance with the LDRD requirement as stated in DOE Order 413.2B and the LDRD SBMS Subject Area.

This includes the Scientific Director arranging for the appropriate peer review in accordance with the Director's guidance utilizing the S-LDRD Review Instruction. 
Project Approval:

After completion of review the projects are then submitted to the Laboratory Director for approval. After approval by the Director all new projects are submitted to the DOE-Brookhaven Site Office (DOE-BHSO) for concurrence by the DOE Project Manager prior to start. The ALDF then sets up a separate laboratory overhead account to budget and collect the costs for the project.

\section{Energy Initiative}

For Fiscal Year 2008 a special call, Exhibit A-2, was released for energy-related R\&D in support of the Laboratory's strategy in this area. The challenges that the Laboratory seeks to address are outlined in the Laboratory Energy Strategy and in a series of white papers that were developed in support of this strategy. We anticipate funding projects aimed at the development of new competencies at BNL. Hence they will be funded at somewhat higher levels than in the past, and for the full 36 months. The business case, including the potential for follow-on funding for these proposals, will held to a high standard.

A side bar to the LDRD web page was established to provide information related to this call, including the energy strategy and white papers as well as review procedures and criteria. It is important to note that proposals submitted in response to this call utilize a different format and were reviewed using criteria and a process that is somewhat different than for the open LDRD call, especially insofar as internal and external written reviews were required. See Exhibit B-2, which is a special Performance Information Questionnaire, giving explicit instructions.

\section{Project Supervision:}

The SD for LDRD carries out overall supervision of projects for all LDRD categories. Supervision over the actual performance of LDRD projects is carried out in the same way as other research projects at the Laboratory. Each principal investigator is assigned to an organizational unit (Department, Division) that is supervised by a chairperson or manager.

Each chairperson or manager is responsible for seeing that the obligations of the principal investigator are satisfactorily fulfilled and that the research itself is carried out according to standard expectations of professionalism and scientific method. The SD monitors the project's status, schedule, and progress and coordinates with the chairperson or manager as necessary.

The SD organizes a mid-year review of all projects. Each PI presents a progress report on the status of their project. In attendance are the SD, the PSP, the DDS\&T, the cognizant ALD and Department Chair, and a representative from the ALDF and DOE-BHSO. This review checks on the progress of the projects including its funding schedule. This allows the SD to ensure that the work be completed in a timely manner. If adequate progress has not been made, projects can be terminated at this time.

In addition, the SD conducts a monthly meeting with the DOE LDRD Project Manager to update the progress of the program and to solicit assistance to verify that the BNL LDRD Program is meeting the overall LDRD requirements. This includes providing the DOE-BHSO with copies of all funded proposals, an LDRD Program database, and a project funding and schedules summary report. 
Project Reporting:

Routine documentation of each project funded under the LDRD Program consists of a file containing: (1) a copy of the written proposal; (2) all interim status reports; (3) notifications of changes in research direction, if any; (4) midyear review presentations and (5) reports on costs incurred. Also, a formal LDRD Plan, Program Assessment Report and the Annual Report on the LDRD Program are submitted to BNL management and the DOE summarizing work progress, accomplishments, and project status on all projects.

Documentation for the overall Program consists of (1) various program history files, (2) a running list of all proposals with their acceptance/rejection status, (3) funding schedule and summary reports for all approved projects, (4) permanent records on cost accounting, and a database containing information on each funded project (description, funding by fiscal year, status and accomplishments, follow-on funding, publications, etc.), (5) midyear review progress reports. A Data Collection Form (Exhibit C) is also utilized to formally collect information on the impacts of the projects. Each project is tracked for two years after its completion so as to gather a complete set of data on the impact of the project. Also, we input LDRD data into the DOE-Chief Financial Officer's Laboratory/ Plant Directed Research and Development Web Site (https://ldrdrpt.doe.gov) to support DOE reporting of LDRD to Congress.

Some of the projects may involve animals or humans. Those projects will have received approval from the Laboratory's appropriate review committees. The projects which involve animals or humans are identified in this report as follows:

"Note: This project involves animal vertebrates or human subjects."

All projects selected for approval are reviewed by the BNL Operations Security (OPSEC) Working Committee chair for classification review and operational security considerations. 


\section{Peer Review}

LDRD projects have peer reviews performed in several different ways. Primarily, LDRD research is managed and reviewed by the cognizant Department and Division manager. These projects are a part of the activities of their respective Department and Divisions in which they reside. For the competed LDRD projects the members of the LDRD Section Committee are considered to have sufficient technical knowledge to perform peer reviews of projects during the initial selection process and annual renewal.

For the Strategic LDRD projects a formal peer review is performed on each project prior to final approval. In addition for the Energy Initiative projects, internal and external written reviews are required.

Also, all LDRD projects go through a formal mid-year review (described in the previous section under project supervision) conducted by the SD that includes the Assistant Laboratory Director for Policy and Strategic Planning, the Deputy Director for Science and Technology, the cognizant Department Chair and Associate Laboratory Director, and the DOE-BHSO LDRD Program Manager.

In addition to these peer reviews of the BNL LDRD projects, they are subject to various advisory committees that consist of subject matter experts from academia and industry who conduct peer reviews of LDRD projects as part of a Department's or Laboratory's program review. One such group is the Brookhaven Science Associates' Science and Technology Steering Committee, which performs peer reviews of different Laboratory programs on a rotating basis. There are also periodic reviews of the science at the Laboratory performed by various offices of DOE. 


\section{Financial Overview}

Operating expenses for the LDRD program are funded through the Laboratory's overhead budget, which is derived from a uniform assessment against all programmatic and Work for Other (WFO) activities performed at the Laboratory. In March of 2006, the DOE-CFO issued guidance that the LDRD Program will be "treated in a manner consistent with the method for distributing the general and administrative (G\&A) expenses of a site.” Therefore, BNL removed LDRD from the G\&A pool and implemented a separate LDRD burden in order to obtain its funds.

At BNL, the LDRD Program was historically a much smaller portion of the total budget than at comparable National Laboratories. Accordingly, the LDRD budget has been significantly increased over the past ten years from $\$ 2.0$ million to $\$ 15.5$ million, or from less than $1 \%$ to almost $2.8 \%$ of the Laboratory cost of $\$ 470$ million, which does not include construction costs. The target level is to increase the level to about $4 \%$, which would still be less than the DOE maximum ceiling of $8 \%$. This better enables the Laboratory for preparing itself for work in emerging areas of research.

In FY 2007, the BNL LDRD Program funded 74 projects, 36 of which were new starts, at a total cost of $\$ 10,222,889$. See Appendix A for a complete list of FY 2007 active projects. The majority of the planned LDRD budget is allocated at the beginning of the fiscal year. Approximately 20\% of the funds were allocated to the Strategic LDRD pool and the remaining $80 \%$ was awarded to competed LDRD projects. A summary of the history of LDRD projects is show below.

A brief description of the FY 2008 new startups and the budgets is given in Exhibit H. These do not include the yet to be approved LDRD Projects from the Energy Initiative. 


\begin{tabular}{|c|c|c|c|c|c|c|}
\hline $\mathbf{F Y}$ & $\begin{array}{c}\text { DOE AUTH. } \\
\mathbf{\$ K}\end{array}$ & $\begin{array}{c}\text { BNL AUTH. } \\
\mathbf{\$ K}\end{array}$ & $\mathbf{C O S T E D ~ \$ K}$ & NO. RECD. & $\begin{array}{c}\text { NEW } \\
\text { STARTS }\end{array}$ & $\begin{array}{c}\text { TOTAL } \\
\text { FUNDD }\end{array}$ \\
\hline 1985 & 4,000 & 1,842 & 1,819 & 39 & 13 & 13 \\
\hline 1986 & 4,500 & 2,552 & 2,515 & 22 & 15 & 25 \\
\hline 1987 & 4,000 & 1,451 & 1,443 & 29 & 8 & 17 \\
\hline 1988 & 4,000 & 1,545 & 1,510 & 46 & 14 & 23 \\
\hline 1989 & 4,000 & 2,676 & 2,666 & 42 & 21 & 29 \\
\hline 1990 & 4,000 & 2,008 & 1,941 & 47 & 9 & 26 \\
\hline 1991 & 2,000 & 1,353 & 1,321 & 23 & 14 & 21 \\
\hline 1992 & 2,500 & 1,892 & 1,865 & 30 & 14 & 25 \\
\hline 1993 & 2,500 & 2,073 & 2,006 & 35 & 14 & 28 \\
\hline 1994 & 2,500 & 2,334 & 2,323 & 44 & 15 & 27 \\
\hline 1995 & 2,500 & 2,486 & 2,478 & 46 & 13 & 31 \\
\hline 1996 & 3,500 & 3,500 & 3,050 & 47 & 17 & 31 \\
\hline 1997 & 4,500 & 4,500 & 3,459 & 71 & 10 & 28 \\
\hline 1998 & 3,500 & 4,000 & 2,564 & 53 & 4 & 20 \\
\hline 1999 & 4,750 & 4,612 & 4,526 & 67 & 25 & 33 \\
\hline 2000 & 6,000 & 6,000 & 5,534 & 93 & 21 & 45 \\
\hline 2001 & 6,000 & 6,000 & 5,345 & 97 & 38 & 70 \\
\hline 2002 & 7,000 & 7,000 & 6,732 & 87 & 29 & 70 \\
\hline 2003 & 8,500 & 8,482 & 7,830 & 153 & 44 & 83 \\
\hline 2004 & 9,500 & 8,550 & 7,209 & 107 & 19 & 72 \\
\hline 2005 & 10,500 & 9,073 & 8,379 & 114 & 41 & 78 \\
\hline 2006 & 11,500 & 9,127 & 11,102 & 96 & 28 & 85 \\
\hline 2007 & 15,500 & 13,600 & 10,223 & 99 & 36 & 74 \\
\hline TOTALS & 127,250 & 106,656 & 97,840 & 1,487 & 462 & 954 \\
\hline & & & & & & \\
\hline
\end{tabular}




\section{Relatedness of LDRD to Laboratory Programs and Initiatives}

BNL's mission is to produce excellent science in a safe, environmentally benign manner with the cooperation, support, and appropriate involvement of our many communities. The Laboratory's core competence lies in five areas:

Design, Construct, and operate extraordinary facilities

Advanced concepts of accelerators, detectors, magnets and instrumentation

Synchrotron radiation sciences and technologies

Imaging expertise

Scientific computing

Research initiatives are a primary tool by which the Laboratory builds core competences and capabilities in particularly promising areas of science and technology and to meet anticipated national needs. The LDRD plays an important role in realizing successful outcomes for its initiatives by providing resources in key areas of initiative development. Each year Laboratory management carefully reviews both existing research initiatives and proposed new areas for progress, scientific and technological promise, their match to BNL's strengths and mission roles, and relevance to DOE missions and evolving national needs. As part of the review process, management identifies the needs for each initiative. These areas are subsequently included in the annual LDRD call for proposals and given high priority for funding. Development of capabilities in these areas is essential to realizing successful outcomes for our initiatives.

Building on its suite of core competencies, the major initiatives, which the Laboratory undertook to achieve these goals for FY 2008, are: Research in Light Source Instrumentation and Techniques - Research in advanced concepts and instrumentation with the potential to expand the capabilities of BNL's Light Sources (present, planned, and possible future) which might lead to a new technique, substantial improvement(s) to existing technique(s), or to development of new, advanced instrumentation and/or sources. Proposals that establish ties between Laboratory programs and the Light Sources are of particular interest.

Evolution of RHIC to a QCD Lab - Research that supports the Laboratory's vision to develop a QCD Laboratory at RHIC, with a particular emphasis on projects focused on research in the physics of the electron-ion collider; the physics opportunities enabled by the electron-ion collider, machine and detector concepts studies, proof of concept experiments, etc.

Computational Science - The 100Tflop SBU/BNL BlueGene/L (BG/L) computer is an outstanding resource now available to BNL scientists. This year, we encouraged projects to begin to utilize this machine. Proposals to migrate current computation efforts to BG/L and/or new efforts that expand the range of scientific applications that would run on the BG/L computer are of particular interest. 
Energy - The subject of a second call for proposals was issued in the late spring of 2007, in support of the Laboratory's strategic plan in Energy R\&D. The areas for the Energy R\&D call were Biofuels, Solar Energy, Advanced Materials, Catalysis, and Nuclear Energy.

The LDRD program included these initiatives in its call for proposals for FY 2008. See Exhibit A. A listing of the FY 2008 projects by initiatives is presented as Exhibit I. Below is a chart reflecting the distribution of projects by laboratory initiatives. These initiatives are aligned with the DOE Office of Science initiatives. 
Targeted FY08 LDRD Allocation (December 07)

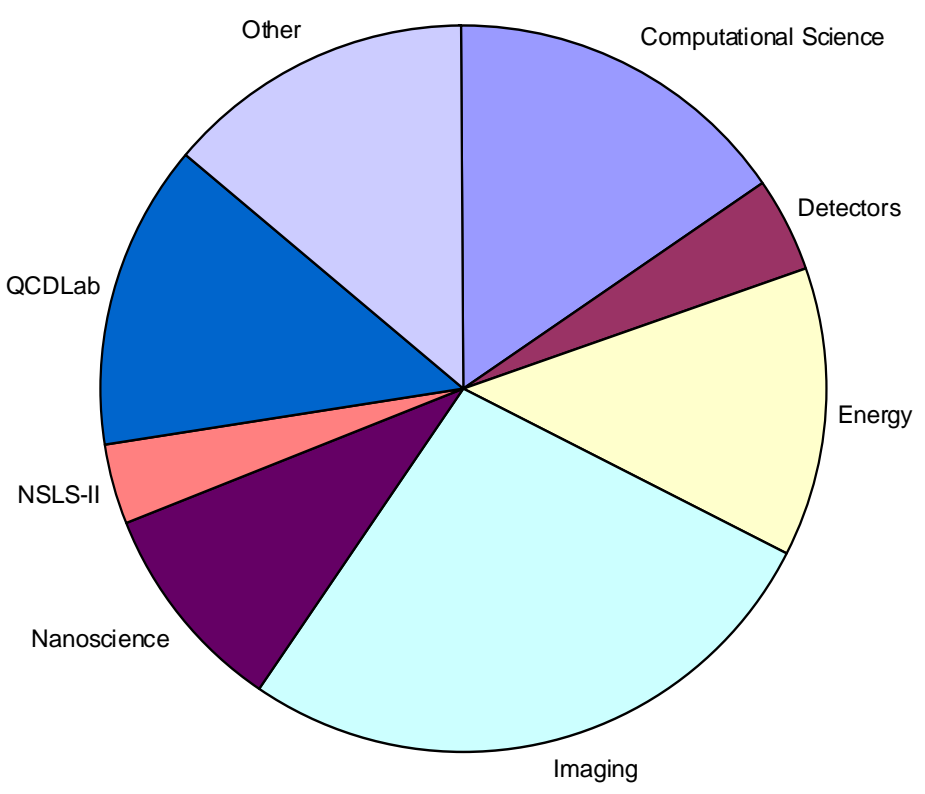




\section{Self Assessment}

BNL supports the concept of continual improvement as part of its management of the Laboratory. To achieve this goal, every year BNL performs self-assessments of various functions at the Laboratory. One of the programs for which the Laboratory conducts a yearly self-assessment is the LDRD program.

In FY 2007, many aspects of the program were reviewed. The following activities contributed to the Laboratory's self-assessment of the LDRD program in FY 2007:

- Annual Program Review at Pacific Northwest National Laboratory (PNNL) in May 2007

- Review of BNL's selection process in August 2007 for Openly Competed Projects

- Review of BNL's selection process for the Energy-related LDRD Projects

\section{LDRD Program Review in May 2007}

PNNL hosted the annual LDRD program review conducted by John LaBarge of the Office of Science (SC) of the U.S. Department of Energy (DOE). The review took place on May 16 and 17, 2007 in two phases and was attended by representatives from across the DOE complex, including BNL. A review of the PNNL program including management, administration, and a sampling of LDRD projects comprised day one and part of day two. The afternoon of the second day focused on the other DOE SC Laboratory LDRD programs and system-wide topics that included the following items:

- Review of the LDRD Order for any comments

- Review of the Roles, Responsibilities and Guidelines for LDRD for any comments

- Discussion on intended uses of LDRD

- Discussion of strategic initiatives vs. seed projects in the Labs' LDRD portfolios

- Discussion of peer review and its importance to the LDRD programs

- Development of on-line systems for the execution and administration of the LDRD programs

- Possible harvesting of the LDRD program by DHS

At the conclusion of the review, DOE conducted an out-briefing, which did not contain any actions for BNL.

\section{Background on the FY 2008 Selection Process}

For FY 2008, BNL made a significant change to the overall Selection Process by issuing two different calls for LDRD proposals. The first call, announced in March 2007, was an open call for proposals and akin to past solicitations. The second call, was focused on energy related R\&D in support of the Lab's strategic plan in energy R\&D whose aim is to conduct basic/applied research underlying breakthroughs in the effective use of renewable energy through improved conversion, transmission, and storage. 
Review of BNL's Selection Process Review for Openly Competed Projects (the existing process)

As part of the annual assessment for the openly competed projects, the Assistant Laboratory Director (ALD) for Policy and Strategic Planning met with the Deputy Director for Science and Technology, the Science ALDs, and members of the Brookhaven Council to solicit feedback on the LDRD selection process.

- In general, their comments were helpful and some logistical changes to the process will likely occur in the future.

The Selection Committee continues to include five members of the BNL Council, as well as the five Science ALDs, and the ALD for Policy and Strategic Planning.

- This provides broad vetting and effective peer review of the proposals.

The LDRD Program continues to emphasize that funding would be provided for two years (twenty four months). A third year may be funded under exceptional circumstances.

- This permits BNL to fund more projects in subsequent years.

The process for approving new projects will not change. Existing projects and some key new projects will continue to be approved to start on October $1^{\text {st }}$ of each year. The remaining new projects will have a start date scheduled for on or about January $1^{\text {st }}$.

- This provides greater flexibility for Laboratory management during years in which a Continuing Resolution creates some uncertainty in the annual budgets. It also recognizes spending reality. Most new LDRDs have significant slippage in the spending, as typically they support post-doctoral researchers, who are usually delayed in coming on board.

The program will continue to hold a mid-year review to assess the project's progress The Principal Investigator of each project will continue to be required to present a formal progress report once during its life cycle.

- This is a factor in determining whether a project would continue into the next fiscal year. In fact, to prepare for this important review, most Directorates now conduct preliminary reviews of the projects prior to the Laboratory formal mid-year review.

The LDRD Scientific Director will continue to meet monthly with the DOE Brookhaven Site Office (BHSO) LDRD Program Manager

- This is an important mechanism for communicating the progress of the program and for verifying that it is meeting the overall LDRD requirements.

\section{Review of BNL's Selection Process for the Energy-related LDRD Projects (a new process)}

For the Energy projects, BNL made significant changes to the selection criteria, in terms of their overall scope and timeline. The projects were expected to support the Lab's energy strategy in areas of solar energy, catalysis, biofuels, and complex materials, although other innovative energy-related ideas were not discounted. They were also expected to be interdisciplinary, team-oriented, and 
extend for three years.

- This will enable the development of new BNL core competencies.

Since these proposals are critical to furthering the Lab's energy strategy, more comprehensive in nature, and funded at higher levels, BNL implemented, on a trial basis, external peer reviews of every energy-related LDRD that was received.

- Although it took longer than expected to obtain the external reviews (with the process continuing into FY 2008), they provided critical feedback to the LDRD Committee that was helpful in their initial selection to identify the best proposals.

For all proposals, the Selection Committee provided written feedback based on the reviewers' comments and the Committee's discussion to the Principal Investigators (PIs).

- The added value was threefold. The comments reinforced the proposals' creative nature and offered suggested improvements. For those proposals not selected, the comments were intended to help the PIs rethink and refocus their ideas.

The PIs of those proposals selected for further consideration were invited to defend their proposed research to the Selection Committee.

- This gave the Selection Committee the opportunity to hear directly from the PIs (rather than the ALDs) about the aims of the proposed work, the research plan, and the expected outcomes of the proposed research via a direct dialogue.

Since the Selection Committee Members agreed that these additional steps resulted in a set of superb proposals, this process will likely be used again for a future focused LDRD selection. Similar to the general proposals, BNL envisions reviewing these proposals annually to ensure that they are meeting the Lab's overall expectations.

\section{Conclusions}

In summary, BNL concludes from its self assessment of the LDRD program that it is working effectively. BNL will maintain its support of any new LDRD requirements and strive to continually improve by:

- $\quad$ Participating in any new DOE SC LDRD working group to develop new guidelines

- Implementing any changes to the DOE Chief Financial Officer (CFO) LDRD database

- Ensuring that all projects support the DOE security missions and missions of other federal agencies

- Continuing to include the DOE-BHSO LDRD Program Manager in all LDRD selection meetings

- Conducting an annual Program Self Assessment. 


\section{Summary of Success Indicators}

Statistical data is collected on all projects for the annual report. Since the LDRD Program is intended to promote high-risk research, the data collected has nominal value on a project-by-project basis. It does provide a general overall picture of the productivity of the LDRD Program.

Some of the more common indicators/measures of success are: 1) the number of proposed, received and approved projects, 2) amount of follow-on funding, 3) the number of patents applied for, and 4) the number of articles published in peer-reviewed journals.

Historically, statistics on the number of projects approved, compared to those rejected, show an overall approval rate of about 30 percent for new starts. Essentially all of the scientific departments were represented in the FY 2007 LDRD Program. The LDRD Program at BNL is expanding and is generating interest from across the entire Laboratory population.

An analysis of the FY 2007 projects shows that many of the projects were reported to have submitted proposals for grants or follow-on funding (several received funding), and a multitude of articles or reports were reported to be in publication or submitted for publication. A summary of success indicators for the FY 2007 projects is shown in the Table, but note that what is provided are only those accomplishments that occurred during the stated fiscal year and thus is not a summary of all the accomplishments from the projects.

\begin{tabular}{|l|c|}
\hline \multicolumn{1}{|c|}{$\begin{array}{c}\text { SUCCESS INDICATORS } \\
\text { FY 2007 }\end{array}$} & QTY \\
\hline $\begin{array}{l}\text { Total number of publications originating in whole or part that were published or } \\
\text { submitted this fiscal year }\end{array}$ & 145 \\
\hline $\begin{array}{l}\text { Total number of formal presentations originating in whole or in part including } \\
\text { those that have been accepted for presentation but not yet presented during this } \\
\text { fiscal year }\end{array}$ & 315 \\
\hline Total number of reports originating in whole or in part during this fiscal year. & 25 \\
\hline $\begin{array}{l}\text { Total number of patents and licenses originating in whole or in part during this } \\
\text { fiscal year. }\end{array}$ & 5 \\
\hline $\begin{array}{l}\text { Total number of copyrights issued/granted during this fiscal year, including those } \\
\text { from follow on funding. }\end{array}$ & 1 \\
\hline $\begin{array}{l}\text { Total number of invention disclosures submitted during this fiscal year to the } \\
\text { Laboratory's Office of Intellectual Property \& Sponsored Research that were } \\
\text { either directly derived from the LDRD or from any follow-on efforts. }\end{array}$ & 9 \\
\hline Total number of formal review presentations conducted during this fiscal year. & 29 \\
\hline $\begin{array}{l}\text { Total number of postdoctoral researchers and graduate students supported in full } \\
\text { or in part during the fiscal year. }\end{array}$ & 57 \\
\hline $\begin{array}{l}\text { Total number of scientific and technical research staff hired during this fiscal } \\
\text { year. }\end{array}$ & 25 \\
\hline Total number of requests for follow on funding submitted this fiscal year. & 61 \\
\hline
\end{tabular}




\begin{tabular}{|l|c|}
\hline \multicolumn{1}{|c|}{$\begin{array}{c}\text { SUCCESS INDICATORS } \\
\text { FY 2007 }\end{array}$} & QTY \\
\hline $\begin{array}{l}\text { Total number of national awards or recognitions received this fiscal year that are } \\
\text { attributable in whole or in part from the project. }\end{array}$ & 3 \\
\hline
\end{tabular}

In conclusion, the overall LDRD Program has been successful. In FY 2007, the LDRD Program has improved on the level established in FY 2006 which already was at a high level. This increase in size is a consequence of the identification of the LDRD Program by Laboratory Management to be an important part of its future. The LDRD Program is a key component for developing new areas of science for the Laboratory. In FY 2007 the Laboratory continued to experience a significant scientific gain by the achievements of the LDRD Projects. 
Funding Table of LDRD Projects Approved FY 2007

Appendix A

\begin{tabular}{|c|c|c|c|c|c|c|c|c|c|}
\hline $\begin{array}{l}\text { Proj. } \\
\text { No. }\end{array}$ & Project Title & P.I. & Dept./BIdg. & $\begin{array}{c}\text { FY05 } \\
\text { no G\&A }\end{array}$ & Actual FY06 & $\begin{array}{l}\text { Actual } \\
\text { FY07 }\end{array}$ & FY08 & FY09 & Total \\
\hline $04-038$ & $\begin{array}{l}\text { Complex Thin Films and Nanomaterial } \\
\text { Properties }\end{array}$ & Misewich, J. & CMPMSD/480 & 190,532 & 370,772 & 193,935 & & & 755,239 \\
\hline $05-006$ & Heavy Ion Physics with the ATLAS Detector & Takai, H. & PHYS/510A & 5,623 & 124,143 & 64,333 & & & 194,099 \\
\hline 05-028 & $\begin{array}{l}\text { Behavior of Water on Chemically Modified } \\
\text { Semiconductor Surfaces: Toward } \\
\text { Photochemical Hydrogen Production }\end{array}$ & Fujita, E. & CHEM/555A & 89,092 & 159,760 & 40,089 & & & 288,941 \\
\hline 05-041 & Multifunctional Nanomaterials for Biology & Wong, S. & CMPMSD/480 & 128,192 & 145,480 & 24,867 & & & 298,539 \\
\hline 05-044 & $\begin{array}{l}\text { Intense THz Source \& Application to } \\
\text { Magnetization Dynamics }\end{array}$ & Carr, G. L. & NSLS/725D & 50,175 & 131,904 & 63,908 & & & 245,987 \\
\hline 05-048 & $\begin{array}{l}\text { Nano-Imaging of Whole Cells with Hard X-Ray } \\
\text { Microscopy }\end{array}$ & Miller, L. & NSLS/725D & 19,496 & 91,159 & 75,631 & & & 186,286 \\
\hline 05-058 & $\begin{array}{l}\text { Development of Methodologies for Analyzing } \\
\text { Transcription Factor Binding in Whole Genomes }\end{array}$ & Anderson, C. & $\mathrm{BIO} / 463$ & 92,970 & 143,704 & 71,979 & & & 308,653 \\
\hline 05-068 & $\begin{array}{l}\text { Positron Labeled Stem Cells for Non-Invasive } \\
\text { PET Imaging Studies of In-Vivo Trafficking and } \\
\text { Biodistribution }\end{array}$ & Srivastava, S. & MED/801 & 63,600 & 140,374 & 150,857 & & & 354,831 \\
\hline 05-070 & $\begin{array}{l}\text { Novel Multi-Modality MRI and Transcranial } \\
\text { Magnetic Stimulation to Study Brain } \\
\text { Connectivity }\end{array}$ & $\begin{array}{l}\text { de Castro } \\
\text { Caparelli, E. }\end{array}$ & MED/490 & 105,571 & 145,397 & 17,673 & & & 268,641 \\
\hline 05-072 & $\begin{array}{l}\text { Feasibility of CZT for Next-Generation PET } \\
\text { Performance }\end{array}$ & Vaska, P. & MED/490 & 111,425 & 135,784 & 146,903 & & & 394,112 \\
\hline 05-074 & Biology on Massively Parallel Computers & Davenport, J. W. & CsC/463B & 168,787 & 222,345 & & & & 391,132 \\
\hline 05-104 & $\begin{array}{l}\text { Giant Proximity Effect (GPE) in High- } \\
\text { Temperature Superconductors }\end{array}$ & Bozovic, I. & CMPMSD/480 & 267,837 & 366,753 & 253,039 & & & 887,629 \\
\hline $05-110$ & Computational Science & Davenport, J. & CSC/463B & & & 58,056 & & & 58,056 \\
\hline $05-114$ & Study of High-Tc Nanostructures & Bozovic, I. & CMPMSD/480 & 265,787 & 367,090 & 257,238 & & & 890,115 \\
\hline
\end{tabular}


Funding Table of LDRD Projects Approved FY 2007

Appendix A

\begin{tabular}{|c|c|c|c|c|c|c|c|c|c|}
\hline $\begin{array}{l}\text { Proj. } \\
\text { No. }\end{array}$ & Project Title & P.I. & Dept./BIdg. & $\begin{array}{c}\text { FY05 } \\
\text { no G\&A }\end{array}$ & Actual FY06 & $\begin{array}{l}\text { Actual } \\
\text { FY07 }\end{array}$ & FY08 & FY09 & Total \\
\hline |06-001 & $\begin{array}{l}\text { Lattice Studies of QCD Thermodynamics on the } \\
\text { QCDOC }\end{array}$ & Karsch, F. & PHYS/510A & & 158,792 & 157,655 & & & 316,447 \\
\hline 06-004 & $\begin{array}{l}\text { Detector Development for Very Long Baseline } \\
\text { Neutrino Exp. }\end{array}$ & Diwan, M. & PHYS/510E & & 66,230 & 101,110 & 100,362 & & 267,702 \\
\hline |06-012 & $\begin{array}{l}\text { Detector for High Quality Images of Electron } \\
\text { Microscopy }\end{array}$ & Rehak, P. & INST/535B & & 70,180 & 140,791 & 71,000 & & 281,971 \\
\hline 06-017 & Transmission Photocathode Development & Smedley, J. & INST/535B & & 67,470 & 134,846 & 67,000 & & 269,316 \\
\hline 06-021 & $\begin{array}{l}\text { Synthesis and Characterization of Band-Gap- } \\
\text { Narrowed TiO2 Thin Films and Nanoparticles for } \\
\text { Solar Energy Conversion }\end{array}$ & Sutter, E. & CFN/480 & & 69,484 & 208,731 & 138,000 & & 416,215 \\
\hline |06-026 & $\begin{array}{l}\text { Multiscale Analysis of In Vivo Nanoparticle } \\
\text { Exposure }\end{array}$ & Schiffer. W. K. & MED/490 & & 192,178 & 188,164 & & & 380,342 \\
\hline 06-030 & $\begin{array}{l}\text { Development of Gadolinium-Loaded Liquid- } \\
\text { Scintillators with Long-Term Chemical Stability } \\
\text { for a New High-Precision Measurement of the } \\
\text { Neutrino Mixing Angle, Theta-13 }\end{array}$ & Hahn, R. L. & CHEM/555A & & 199,946 & 190,494 & 100,000 & & 490,440 \\
\hline 06-037 & $\begin{array}{l}\text { Electronic Properties of Carbon Nanotubes and } \\
\text { Novel Multicomponent Nanomaterials }\end{array}$ & Hill, J.P. & CMPMSD/510B & & 45,590 & 179,435 & 90,000 & & 315,025 \\
\hline 06-038 & $\begin{array}{l}\text { Growth and Characterization of CdZnTe } \\
\text { Crystals for Improved Nuclear Radiation } \\
\text { Detectors }\end{array}$ & Gu, G. & CMPMSD/510A & & 24,292 & 150,529 & 131,000 & & 305,821 \\
\hline $06-038$ & $\begin{array}{l}\text { Growth and Characterization of CdZnTe } \\
\text { Crystals for Improved Nuclear Radiation } \\
\text { Detectors (duplicate of above) }\end{array}$ & Bolotnikov, A. E. & NNS/197D & & 38,640 & 37,169 & & & 75,809 \\
\hline 06-039 & $\begin{array}{l}\text { Design, Synthesis and Characterization of a } \\
\text { New Class of Hydrocarbon Polymers Containing } \\
\text { Zwitter lons and Nanostructured Composites for } \\
\text { High Temperature Membrane in PEM Fuel Cells }\end{array}$ & Yang, X. -Q. & CMPMSD/555 & & 133,331 & 130,812 & & & 264,143 \\
\hline 06-046 & Novel Materials for Hard X-Ray Optics & $\begin{array}{l}\text { Evans-Lutterodt, } \\
\text { K. }\end{array}$ & NSLS/725D & & 24,809 & 157,550 & 120,000 & & 302,359 \\
\hline
\end{tabular}


Funding Table of LDRD Projects Approved FY 2007

Appendix A

\begin{tabular}{|c|c|c|c|c|c|c|c|c|c|}
\hline $\begin{array}{l}\text { Proj. } \\
\text { No. }\end{array}$ & Project Title & P.I. & Dept./BIdg. & $\begin{array}{c}\text { FY05 } \\
\text { no G\&A }\end{array}$ & Actual FY06 & $\begin{array}{l}\text { Actual } \\
\text { FY07 }\end{array}$ & FY08 & FY09 & Total \\
\hline 06-047 & $\begin{array}{l}\text { Nano-Crystallography of Individual Nanotubes } \\
\text { and Nanoparticles }\end{array}$ & Nelson, C. & NSLS/725D & & 62,673 & 142,182 & 66,000 & & 270,855 \\
\hline 06-052 & $\begin{array}{l}\text { High-Temperature Superconducting Magnet } \\
\text { Development }\end{array}$ & Tanabe, $T$. & NSLS/725C & & 236,846 & 209,443 & & & 446,289 \\
\hline |06-056 & $\begin{array}{l}\text { Epigenetics: Methamphetamine (MAP)-Induced } \\
\text { Brain Dysfunction and Methylation of DNA }\end{array}$ & Dunn, J. J. & $\mathrm{BIO} / 463$ & & 76,620 & 115,760 & 157,000 & & 349,380 \\
\hline 06-060 & $\begin{array}{l}\text { Molecular Mechanism of Chromosomal } \\
\text { Replication Initiation in Eukaryotic System }\end{array}$ & Li, H. & $\mathrm{BIO} / 463$ & & 101,859 & 210,492 & 106,000 & & 418,351 \\
\hline $06-061$ & Diversification of Isoflavonoid Biosynthesis & Liu, C. -J. & $\mathrm{BIO} / 463$ & & 437,328 & 477,915 & 200,000 & & $1,115,243$ \\
\hline 06-065 & Metabolic Flux Analysis in Arabidopsis Thaliana & Schwender, J. & $\mathrm{BIO} / 463$ & & 425,511 & 469,343 & & & 894,854 \\
\hline 06-066 & $\begin{array}{l}\text { Transformation and Fate of Nanomaterials in } \\
\text { the Environment }\end{array}$ & Fitts, J. & ESD/830 & & 140,086 & 147,694 & & & 287,780 \\
\hline 06-071 & $\begin{array}{l}\text { Development of a Cloud Condensation Nucleus } \\
\text { Separator }\end{array}$ & Wang, J. & ESD/815E & & 69,661 & 139,591 & 70,000 & & 279,252 \\
\hline 06-074 & $\begin{array}{l}\text { Aluminum Hydride - An Ideal Hydrogen Source } \\
\text { for Small Fuel Cells }\end{array}$ & Graetz, J. & ES\&T/815 & & 132,601 & 133,579 & & & 266,180 \\
\hline 06-087 & $\begin{array}{l}\text { Gamma Ray Imager for National Security } \\
\text { Applications }\end{array}$ & Vanier, P. E. & NNS/197C & & 110,380 & 156,670 & & & 267,050 \\
\hline 06-088 & $\begin{array}{l}\text { Neurogenomics: Collaboration Between the } \\
\text { Biology Department and the Brookhaven Center } \\
\text { for Translational Neuroimaging to Investigate } \\
\text { Complex Disease States }\end{array}$ & $\begin{array}{l}\text { Alia-Klein, } \\
\text { N./Fowler, J.S. }\end{array}$ & MED/490 & & 149,971 & 152,363 & & & 302,334 \\
\hline 06-092 & $\begin{array}{l}\text { Nanoparticle Labeled Neural Stem Cell Tracking } \\
\text { In Vivo by Magnetic Resonance Microscopy }\end{array}$ & \begin{tabular}{|l} 
Foerster, B. \\
(leaving Lab) \\
Benveniste, H.
\end{tabular} & MED/490 & & 109,022 & 69,428 & 50,000 & & 228,450 \\
\hline
\end{tabular}


Funding Table of LDRD Projects Approved FY 2007

Appendix A

\begin{tabular}{|c|c|c|c|c|c|c|c|c|c|}
\hline $\begin{array}{l}\text { Proj. } \\
\text { No. }\end{array}$ & Project Title & P.I. & Dept./BIdg. & $\begin{array}{c}\text { FY05 } \\
\text { no G\&A }\end{array}$ & Actual FY06 & $\begin{array}{l}\text { Actual } \\
\text { FY07 }\end{array}$ & FY08 & FY09 & Total \\
\hline 06-094 & $\begin{array}{l}\text { MicroCT Methods of Quantitative Adipose } \\
\text { Imaging: Development of a Long-Term } \\
\text { Assessment Technique for Studying Obesity in } \\
\text { a Rodent Model }\end{array}$ & Wang, G. J. & MED/490 & & 77,143 & 197,924 & 82,000 & & 357,067 \\
\hline $06-097$ & $\begin{array}{l}\text { Photocatalytic Reduction of } \mathrm{CO} 2 \text { in Supercritical } \\
\mathrm{CO} 2\end{array}$ & Grills, D. & CHEM/555 & & 80,098 & 155,011 & 71,000 & & 306,109 \\
\hline |07-001 & $\begin{array}{l}\text { QCD Thermodynamics at Non-zero } \\
\text { Temperature and Density }\end{array}$ & Karsch, F. & PHYS/510A & & & 389,374 & 408,000 & & 797,374 \\
\hline 07-002 & Lattice QCD Simulations on BlueGene/L & Karsch, F. & PHYS/510A & & & 147,308 & 189,000 & 49,000 & 385,308 \\
\hline $07-004$ & $\begin{array}{l}\text { Proof-of-Principle Laser System for ILC Positron } \\
\text { Source }\end{array}$ & Pogorelsky, I. & PHYS/820M & & & 30,202 & 126,000 & 31,000 & 187,202 \\
\hline 07-005 & $\begin{array}{l}\text { Sensitive Searches for CP-Violation in Hadronic } \\
\text { Systems }\end{array}$ & Semertzidis, $Y$ & PHYS/510A & & & 22,183 & 115,000 & 29,000 & 166,183 \\
\hline 07-006 & $\begin{array}{l}\text { Feasibility and Design Studies for a Detector for } \\
e+p, e+A, p+p, p+A \text {, and } A+A \text { Collisions at } B N L\end{array}$ & Ullrich, T. & PHYS/510A & & & 33,626 & 88,000 & 26,500 & 148,126 \\
\hline 07-007 & $\begin{array}{l}\text { A Novel and Compact Muon Telescope Detector } \\
\text { for QCD Lab }\end{array}$ & Xu, Zhangbu & PHYS510A & & & 34,591 & 77,000 & 30,000 & 141,591 \\
\hline 07-010 & $\begin{array}{l}\text { Design Optimization of a Reactor Neutrino } \\
\text { Experiment }\end{array}$ & Jaffe, D. & PHYS/510E & & & 72,262 & 125,000 & 31,000 & 228,262 \\
\hline 07-019 & $\begin{array}{l}\text { Development of Laser beam Shaper for Low } \\
\text { Emittance Electron Beams }\end{array}$ & Rao, $\mathrm{T}$. & INST/535B & & & 148,086 & 249,000 & 50,000 & 447,086 \\
\hline 07-023 & $\begin{array}{l}\text { Surface Engineered and Core-Shell Nanowires: } \\
\text { Nanoscale Building Blocks for Third Generation } \\
\text { Photovoltaics }\end{array}$ & Sutter, P. & CFN/555 & & & 39,534 & 165,000 & 125,000 & 329,534 \\
\hline $07-025$ & $\begin{array}{l}\text { Precision Assembly of Nano-Objects - } \\
\text { Approaching Artificial Photosynthesis }\end{array}$ & Sherman, W. & CFN/463 & & & 40,443 & 135,000 & 90,000 & 265,443 \\
\hline 07-027 & $\begin{array}{l}\text { Photocatalytic Carbon Dioxide Reduction to } \\
\text { Methanol using Metal Complexes with an NADH } \\
\text { Model Ligand }\end{array}$ & Fujita, E. & CHEM/555A & & & 78,581 & 165,000 & 86,000 & 329,581 \\
\hline
\end{tabular}


Funding Table of LDRD Projects Approved FY 2007

Appendix A

\begin{tabular}{|c|c|c|c|c|c|c|c|c|c|}
\hline $\begin{array}{l}\text { Proj. } \\
\text { No. }\end{array}$ & Project Title & P.I. & Dept./BIdg. & $\begin{array}{c}\text { FY05 } \\
\text { no G\&A }\end{array}$ & Actual FY06 & $\begin{array}{l}\text { Actual } \\
\text { FY07 }\end{array}$ & FY08 & FY09 & Total \\
\hline 07-030 & $\begin{array}{l}\text { Structure of Mass-Size Selected Nanoparticles } \\
\text { by Scanning Transmission Electron Microscopy }\end{array}$ & White, M. & CHEM/555A & & & 96,768 & 125,000 & 31,000 & 252,768 \\
\hline 07-032 & $\begin{array}{l}\text { Synthesis of Conjugated Polymers for } \\
\text { Fundamental Questions in Solar Energy }\end{array}$ & Miller, J. & CHEM/555A & & & 112,702 & 150,000 & 37,000 & 299,702 \\
\hline $07-035$ & Ultra-thin Graphite Analog Compounds & Valla, T. & CMPMSD/480 & & & 86,876 & 121,000 & 30,000 & 237,876 \\
\hline 07-036 & $\begin{array}{l}\text { Lipid-Coated Nanoparticles and Their } \\
\text { Interactions with Lipid Membrane Surfaces }\end{array}$ & Fukuto, M. & CMP/510B & & & 26,982 & 125,000 & 100,000 & 251,982 \\
\hline 07-038 & $\begin{array}{l}\text { Angle-Resolved Time-of-Flight Ion Scattering } \\
\text { Spectroscopy from MBE-Grown Oxide Thin Film } \\
\text { Surfaces }\end{array}$ & Gozar, A. & CMP/480 & & & & 205,000 & 213,000 & 418,000 \\
\hline 07-040 & $\begin{array}{l}\text { Genome Analysis of Endophytic Bacteria that } \\
\text { Promote Growth of Poplar for Biomass } \\
\text { Production }\end{array}$ & Taghavi, S. & BIO/463 & & & 251,949 & & & 251,949 \\
\hline 07-041 & $\begin{array}{l}\text { Structural Features of the Oxygen Tolerant } \\
\text { Hydrogenase from Thermatoga neapolitana }\end{array}$ & Van der Lelie, D. & $\mathrm{BIO} / 463$ & & & 268,175 & & & 268,175 \\
\hline 07-047 & $\begin{array}{l}\text { Characterization of Enzymatic O-acylation to } \\
\text { Facilitate Biomass and Bioenergy Production }\end{array}$ & Liu, C.-J. & $\mathrm{BIO} / 463$ & & & 8,653 & 175,000 & 164,000 & 347,653 \\
\hline $07-048$ & Functional Neurochemistry & Tomasi, D. & MED/490 & & & 4,185 & 125,000 & 120,000 & 249,185 \\
\hline $07-054$ & Miniaturized RF Coil Arrays for MicroMRI & Smith, D. & MED/490 & & & 85,274 & 126,000 & 30,000 & 241,274 \\
\hline 07-055 & $\begin{array}{l}\text { Neurocomputation at BCTN : Developing Novel } \\
\text { Computational Techniques to Study Brain } \\
\text { Function in Health and Disease }\end{array}$ & Goldstein, R. & MED/490 & & & 150,052 & 150,000 & & 300,052 \\
\hline $07-059$ & $\begin{array}{l}\text { A Non-Fermentation Route to Convert Biomass } \\
\text { to Bioalcohols }\end{array}$ & Mahajan, D. & ES\&T/815 & & & 91,924 & 127,000 & 30,000 & 248,924 \\
\hline
\end{tabular}


Funding Table of LDRD Projects Approved FY 2007

Appendix A

\begin{tabular}{|c|c|c|c|c|c|c|c|c|c|}
\hline $\begin{array}{l}\text { Proj. } \\
\text { No. }\end{array}$ & Project Title & P.I. & Dept./BIdg. & $\begin{array}{c}\text { FY05 } \\
\text { no G\&A }\end{array}$ & Actual FY06 & $\begin{array}{l}\text { Actual } \\
\text { FY07 }\end{array}$ & FY08 & FY09 & Total \\
\hline |07-062 & $\begin{array}{l}\text { Fate and Reactivity of Carbon Nanoparticles } \\
\text { (CNPs) Exposed to Aqueous Environmental } \\
\text { Conditions }\end{array}$ & $\begin{array}{l}\text { Panessa-Warren, } \\
\text { B. }\end{array}$ & ES\&T/475C & & & 93,987 & 125,000 & 31,000 & 249,987 \\
\hline 07-073 & $\begin{array}{l}\text { Development of Room-temperature CdMnTe } \\
\text { Gamma-ray Detectors }\end{array}$ & Cui, Y. & NNS/535B & & & 93,736 & 125,000 & 31,000 & 249,736 \\
\hline 07-075 & $\begin{array}{l}\text { Developing a New Framework for Investigating } \\
\text { Earth's Climate and Climate Change }\end{array}$ & Liu, Y. & ESD/815E & & & 98,260 & 125,000 & 31,000 & 254,260 \\
\hline 07-080 & $\begin{array}{l}\text { A Novel Approach for Efficient Biofuel } \\
\text { Generation }\end{array}$ & Chidambaram, D. & ESD/490A & & & 79,625 & 107,000 & 27,000 & 213,625 \\
\hline |07-084 & $\begin{array}{l}\text { Investigations of Hygroscopic Growth and } \\
\text { Phase Transitions of Atmospheric Particles by } \\
\text { Noncontact Atomic Force Microscopy }\end{array}$ & Schwartz, S. & ESD/815E & & & 26,682 & 120,000 & 94,000 & 240,682 \\
\hline $07-089$ & Chemical Imaging of Living Cells in Real Time & Miller, L. & NSLS/725D & & & 43,643 & 115,000 & 69,000 & 227,643 \\
\hline 07-090 & $\begin{array}{l}\text { Coherent Bragg Rod Analysis of High-Tc } \\
\text { Superconducting Epitaxial Films }\end{array}$ & Pindak, R. & NSLS/725D & & & 22,691 & 115,000 & 92,000 & 229,691 \\
\hline $07-091$ & $\begin{array}{l}\text { Development of a Planar Device Technology for } \\
\text { Hyperpure Germanium X-ray Detectors. }\end{array}$ & Siddons, D.P. & NSLS/725D & & & 8,514 & 175,000 & 112,000 & 295,514 \\
\hline 07-096 & $\begin{array}{l}\text { Study of Epigenetic Mechanisms in a Model of } \\
\text { Depression }\end{array}$ & Henn, F. & |LIFE/490 & & & 321,258 & 340,000 & & 661,258 \\
\hline $07-097$ & Polarized Electron SRF Gun & Ben-Zvi, I. & $\mathrm{CAD} / 911 \mathrm{~B}$ & & & 149,879 & 200,000 & 50,000 & 399,879 \\
\hline $07-098$ & New Approach to H Production, Stages and use & Han, W. & CFN & & & 384,523 & 310,000 & & 694,523 \\
\hline $07-100$ & $\begin{array}{l}\text { Increasing the Capability and Reliability of Small } \\
\text { Diameter Direct Wind Multi-layer Coil Magnets }\end{array}$ & Escallier, J. & SMD/902A & & & 346,156 & & & 346,156 \\
\hline $07-101$ & High End Scientific Computing & Davenport, J. & CSC/463B & & & 361,016 & $1,701,000$ & $1,773,000$ & $3,835,016$ \\
\hline
\end{tabular}


Funding Table of LDRD Projects Approved FY 2007

\begin{tabular}{|c|c|c|c|c|c|c|c|c|c|}
\hline $\begin{array}{l}\text { Proj. } \\
\text { No. }\end{array}$ & Project Title & P.I. & Dept./BIdg. & $\begin{array}{c}\text { FY05 } \\
\text { no G\&A }\end{array}$ & Actual FY06 & $\begin{array}{l}\text { Actual } \\
\text { FY07 }\end{array}$ & FY08 & FY09 & Total \\
\hline & & & & $1,559,087$ & $5,845,406$ & $10,222,889$ & & & \\
\hline
\end{tabular}


date: $\quad$ March 28, 2007

to: $\quad$ Scientific Staff

from: $\quad$ L. Newman, Scientific Director, Laboratory Directed Research and Development

subject: $\quad$ Laboratory Directed Research \& Development Program (LDRD) Proposals

We are now soliciting proposals for the annual LDRD competition for awards that will begin in Fiscal Year 2008 (FY08). The process for selection of the LDRD awards will be essentially the same as in past years, but there are notable changes in the program this year. For FY08, we anticipate that we will be able to fund some projects that are aimed at the development of new core competencies at BNL at somewhat higher levels than in the past, with budgets funded for the full 36 months. The business case, including the potential for follow-on funding, for proposals in this 'competence building' class of proposals will be held to a high standard.

As a part of this call, proposals which support the Laboratory Strategic Initiatives (www.bnl.gov/ldrd) are especially encouraged. However, in one strategic area we will follow a different path. As you may be aware, the Laboratory has undertaken an effort to develop a vision and strategy for research and development in energy sciences. This strategy capitalizes on several of the Laboratory's core competencies and facilities and will help define the activities in this area at Brookhaven for the foreseeable future. Consequently, we will be issuing a separate call focused on energy-related proposals later this spring or early in the summer, once the Science and Technology Steering Committee has completed its review of the strategy. At this time, we anticipate that the areas for the energy strategy call will be Biofuels, Solar Energy, Advanced Materials, Catalysis, and Nuclear Energy. The focus of the call for energy proposals will be the "white papers" in these areas that are currently under development by the energy strategy committee chaired by Doon Gibbs. Proposals that specifically support the Laboratory's strategic plan in energy research should not be submitted in response to this call. Further information will be given in the call for those proposals at a later date. In the meantime, you should address questions about the Laboratory's Energy Strategy and the topical white papers to your Associate Laboratory Director (ALD).

The deadline for receipt of proposals is COB April 30, 2007. We ask that you submit your proposal electronically through your respective Chairperson/Division Head and ALD to Sabrina Parrish (LDRD@bnl.gov). In addition, please submit the current version of the Proposal Information Questionnaire (PIQ) form, which can be obtained electronically at https://sbms.bnl.gov/sbmsearch/subjarea/99/3c02e011.doc. I am available to aid individuals in the preparation of a proposal and to answer any questions you may have regarding the LDRD Program. 
As the Congressional budget process has not concluded on-time in the past 12 years, we believe that it is best to plan for funding of new FY08 LDRD projects to begin on January 1, 2008; unless the potential exists at that time for a significant budgetary impact to the Laboratory arising from the appropriations process (which has been the case the last two years.)

All LDRD Proposals will be judged on their merits and appropriateness for funding under the DOE LDRD Guidelines. The specific criteria to be used for selection are:

1) The intellectual merit of the proposed activity.

How important is the proposed activity to advancing knowledge and understanding within its own field or across different fields?

To what extent does the proposed activity suggest and explore creative and original concepts?

Are the proponent(s) qualified to conduct the proposed research?

How well-conceived and organized is the proposed activity?

Is there sufficient access to resources? Is the scope of work commensurate with the requested budget?

2) The broader impacts of the proposed activity on the Laboratory.

Will the activity lead to new capabilities or competencies at the Laboratory?

Will this project help to ensure the scientific and technical vitality of the Laboratory?

Does the proposal foster cross disciplinary and/or cross Organizational Unit collaborations?

Does the proposal appropriately anticipate DOE or other sponsor needs? How can one tell?

As usual, research conducted under the LDRD Program cannot duplicate or directly augment research presently funded at the Lab. The policy and guidelines for the BNL LDRD Program are posted at https://sbms.bnl.gov/sbmsearch/subjarea/99/99_SA.cfm?parentID=99.

The Selection Committee for proposals in response to this call will be chaired by the Scientific Director for LDRD and includes the Assistant Laboratory Director for Policy and Strategic Planning, the Deputy Director for Science and Technology, the ALDs, and members of the Brookhaven Council. The Committee hopes to conclude the selection process by the end of July.

\author{
LN:kjf \\ attachment \\ cc: Level I and II Managers \\ N. Narain
}




\section{Call for LDRD Proposals in Energy-related Research and Development}

We are now soliciting proposals for energy-related LDRD projects in support of the Laboratory's strategy in this area. A webpage has been established to provide information related to this call, including the energy strategy and white papers as well as review procedures and criteria.

Please see: http://www.bnl.gov/ldrd/FY08 EnergyRelated LDRD/. It is important to note that proposals submitted in response to this call will utilize a different format and will be reviewed using criteria and a process that is somewhat different than for the open LDRD call. Please pay close attention to these changes!

The deadline for receipt of proposals is COB July 31, 2007. We ask that you submit your proposal electronically through your respective Chairperson/Division Head and ALD to Sabrina Parrish (Sabrina@bnl.gov). In drafting your proposal, utilize the Proposal Information Questionnaire (PIQ) for Energy-Related LDRD, which is linked to the website listed above. If you have questions, please contact the LDRD Director Lenny Newman (newman@bnl.gov) 
Exhibit B

BROOKHAVEN NATIONAL LABORATORY

PROPOSAL INFORMATION QUESTIONNAIRE

LABORATORY DIRECTED RESEARCH AND DEVELOPMENT PROGRAM

PRINCIPAL INVESTIGATOR

DEPARTMENT/DIVISION

OTHER INVESTIGATORS
PHONE

DATE

\section{TITLE OF PROPOSAL}

\section{PROPOSAL TERM (month/year)}

From

Through

\section{SUMMARY OF PROPOSAL}

\section{Description of Project:}

\section{Expected Results:}

\section{INSTRUCTIONS}

Under Description of Project, provide a summary of the scientific concept of the proposed project including the motivation for the undertaking and the approach that will be used to conduct the investigation. Also indicate how the project meets the general characteristics of the LDRD Program and how it is tied to the DOE Mission.

Under Expected Results, clearly enunciate what are the expected results and how they will impact the science.

These items should not exceed the space remaining on this page, using the given font and size. The content should be understandable by the non-expert. Do not use jargon (defined by Webster as the "technical or secret vocabulary of a science"), as this has no meaning or utility to the non-expert. Submit this Summary of Proposal for review by your ALD. Upon concurrence and possible modification of your summary, follow it with an extended Proposal of no more than three (3) pages in length. In addition, include a one-page Vita of the Principal Investigator; fill out the page with citations to recent pertinent publications. Do not include any additional attachments, as these will be discarded. Complete the Questionnaire, obtain the required approvals, and provide a budget in the format on the form supplied. Break down the funding by fiscal year and by the broad categories of labor, materials and supplies, travel (foreign \& domestic), services and subcontracts. LDRD funds cannot be used to purchase capital equipment. Indicate the intent to use collaborators, postdoctoral research associates, and/or students. Identify the various burdens applied, i.e., organizational, materials, contracts, and any other charges. Include the Laboratory G\&A in the budget statement. Go to the LDRD web site (www.bnl.gov/ldrd/) for further information. The Instructions should be removed before proceeding. 
Exhibit B

PROPOSAL 


\section{Exhibit B}

VITA (Principal Investigator) 
1. HUMAN SUBJECTS (Reference: DOE Order 1300.3)

Are human subjects involved from BNL or a collaborating institution?

If yes, attach copy of the current Institutional Review Board Approval and Informed Consent Form from BNL and/or collaborating institution.

$\mathrm{Y} / \mathrm{N}$

\section{VERTEBRATE ANIMALS}

Are vertebrate animals involved?

If yes, has approval from BNL's Animal Care and Use Committee been obtained?

$\mathrm{Y} / \mathrm{N}$

$\mathrm{Y} / \mathrm{N}$

\section{NEPA REVIEW}

Are the activities proposed similar to those now carried out in the Department/Division which have been previously reviewed for potential environmental impacts and compliance with federal, state, local rules and regulations, and BNL's Environment, Safety, and Health Standards? (Therefore, if funded, proposed activities would require no additional environmental evaluation.)

$\mathrm{Y} / \mathrm{N}$

If no, has a NEPA review been completed in accordance with the Subject Area National Environmental Policy Act (NEPA) and Cultural Resources Evaluation and the results documented?

$\mathrm{Y} / \mathrm{N}$

(Note: If a NEPA review has not been completed, submit a copy of the work proposal to the BNL NEPA Coordinator for review. No work may commence until the review is completed and documented.)

\section{ES\&H CONSIDERATIONS}

Does the proposal provide sufficient funding for appropriate decommissioning of the research space when the experiment is complete?

$\mathrm{Y} / \mathrm{N}$

Is there an available waste disposal path for project wastes throughout the course of the experiment?

$\mathrm{Y} / \mathrm{N}$

Is funding available to properly dispose of project wastes throughout the course of the experiment?

$\mathrm{Y} / \mathrm{N}$

Are biohazards involved in the proposed work? If yes, attach a current copy of approval from the Institutional Biosafety Committee.

$\mathrm{Y} / \mathrm{N}$

Can the proposed work be carried out within the existing safety envelope of the facility (Facility Use Agreement, Nuclear Facility Authorization Agreement, Accelerator Safety Envelope, etc.) in which it will be performed?

$\mathrm{Y} / \mathrm{N}$ 


\section{Exhibit B}

If no, attach a statement indicating what has to be done and how modifications will be funded to prepare the facility to accept the work.

5. TYPE OF WORK

Select Basic, Applied or Development

\section{LINK TO LABORATORY STRATEGIC INITIATIVES}

Identify below if the proposal is in support of RHIC, the Light Source, or any of the

Strategic Initiatives that can be found listed at the LDRD web site, www.bnl.gov/ldrd.

\section{POTENTIAL FUTURE FUNDING}

Identify below the Agencies and the specific program/office, which may be interested in supplying future funding. Give some indication of time frame.

\section{APPROVALS}

Department /Division Administrator

Print Name

Department Chair/Division Manager

Print Name

Cognizant Associate Director

Print Name 
BUDGET REQUEST BY FISCAL YEAR

Exhibit B

\section{Department \\ Title \\ PI}

(Note: Funding for more than 2 years is unlikely and cannot exceed 3 years)

\begin{tabular}{|c|c|c|c|c|}
\hline COST ELEMENT & $\begin{array}{l}\text { FISCAL } \\
\text { YEAR }\end{array}$ & $\begin{array}{l}\text { FISCAL } \\
\text { YEAR }\end{array}$ & $\begin{array}{l}\text { FISCAL } \\
\text { YEAR }\end{array}$ & $\begin{array}{l}\text { TOTAL } \\
\text { COST }\end{array}$ \\
\hline $\begin{array}{l}\text { Labor* } \\
\text { Fringe } \\
\quad \text { Total Labor } \\
\text { Organizational Burden @___ \% }\end{array}$ & & & & \\
\hline DISTRIBUTED TECHNICAL SERVICES & & & & \\
\hline $\begin{array}{l}\text { Materials } \\
\text { Supplies } \\
\text { Travel } \\
\text { Services } \\
\quad \text { Total MST } \\
\text { Materials Burden@_ \% }\end{array}$ & & & & \\
\hline $\begin{array}{l}\text { TECHNICAL COLLABORATORS/ } \\
\text { CONSULTANTS }\end{array}$ & & & & \\
\hline $\begin{array}{l}\text { Sub-contracts } \\
\text { Contracts Burden @__ } \%\end{array}$ & & & & \\
\hline $\begin{array}{l}\text { Electric Power } \\
\text { Other (specify) }\end{array}$ & & & & \\
\hline $\begin{array}{l}\text { Traditional G\&A @ }{ }_{\text {Common Support G\&A @ }}^{\%} \%\end{array}$ & & & & \\
\hline TOTAL PROJECT COST & & & & \\
\hline $\begin{array}{l}\text { *Labor (give levels of effort with names, or if } \\
\text { unknown indicate TBD) } \\
\text { Scientific \& Professional }\end{array}$ & & & & \\
\hline $\begin{array}{l}\text { Post Doc } \\
\text { Other }\end{array}$ & & & & \\
\hline $\begin{array}{l}\text { Note: } \\
\text { The Budget Office covers } 20 \% \text { of the Post Doc's } \\
\text { salary/fringe. }\end{array}$ & & & & \\
\hline List all Materials Costing Over $\$ 5,000$ & & & & \\
\hline
\end{tabular}


Exhibit B-2

\section{BROOKHAVEN NATIONAL LABORATORY \\ PROPOSAL INFORMATION QUESTIONNAIRE FOR ENERGY-RELATED LABORATORY DIRECTED RESEARCH AND DEVELOPMENT PROGRAM}

\section{GENERAL INSTRUCTIONS}

Proposals must conform to the following requirements in the attached Energy LDRD PIQ:

Font: Times New Roman, 12 point. Line spacing: No smaller than single space, 0 point before \& after line. Margins: 1 ” in all directions.

Proposals that do not follow the format will be rejected.

\section{Cover Page}

A cover page must precede each proposal.

\section{Summary of Proposal}

The proposal must contain a summary of the proposed activity, not more than one page in length. The summary should be a self-contained description of the activity that would result if the proposal were funded and include a statement of the objectives and methods to be employed. It should not be an abstract. The summary should be informative to persons from the same field, yet understandable to the more general scientifically literate audiences who are not experts in the field.

\section{Description of Project:}

The Project Description should provide a clear statement of the work to be undertaken and include: the objectives for the period of the proposed work and expected significance; relation to longer-term goals, to the present state of knowledge in the field, to work in progress at BNL under other support, and to work in progress elsewhere; inside or outside of BNL.

The Project Description should outline the general plan of work, including the broad design of activities to be undertaken. As an integral part of the narrative, it must describe the broader impacts resulting from the proposed activities, addressing as appropriate, one or more of the following:

- How the project will further the Laboratory's strategic aims in energy-related R\&D

- How the project will enhance the infrastructure for research at BNL, such as development of new facilities, instrumentation, networks, and partnerships

- How the project relates to the goals of research sponsors at the DOE or elsewhere

- The potential for intellectual property resulting from the research.

Any substantial collaboration with individuals not included in the budget should also be described. The Project Description may not exceed 10 pages.

\section{References}

The proposal may also include a list of references that substantiate assertions of need, scientific or technical barriers, or research results on which the proposed work relies. 


\section{Equipment}

If the proposal includes a request for equipment over $\$ 5000$, a statement of justification is needed for each piece of equipment that is being requested. The statement of justification should include information about the relationship to the proposed work and a statement of the potential impact on the proposed statement of work, if the equipment were not made available, as well as potential alternative solutions (if any).

\section{Biographical Information}

For each of the principal investigators, the proposal must include a one-page CV that lists their education, history of employment and other appointments, areas of expertise, and publications relevant to the proposed work (not to exceed 10).

\section{Reviewers}

Please provide the names and contact information (address, email address, phone number) of three qualified external reviewers who we may contact for a review by mail.

\section{Information about the Proposal}

The questions must be answered and the proposal must be approved by the Department/Division Administrator, the Department Chair/Division Manager, and the Cognizant Associate Laboratory Director.

\section{Budget}

The LDRD Budget Request by Fiscal Year form must be completed. The requested budget should be commensurate with the proposed scope of work and will be considered as one of the review criteria.

Please do not include the instructions with the proposal. 
BROOKHAVEN NATIONAL LABORATORY PROPOSAL INFORMATION QUESTIONNAIRE FOR ENERGY-RELATED LABORATORY DIRECTED RESEARCH AND DEVELOPMENT PROGRAM

COVER PAGE (item 1)

PRINCIPAL INVESTIGATOR

DEPARTMENT/DIVISION

OTHER INVESTIGATORS
PHONE

DATE

\section{TITLE OF PROPOSAL}

\begin{tabular}{|c|c|c|c|c|}
\hline PROPOSAL TERM (month/year) & From & & Through & \\
\hline $\begin{array}{l}\text { FUNDING REQUEST (duration } \\
\text { cannot exceed thirty six months) }\end{array}$ & FY08 & FY09 & FY10 & FY11 \\
\hline
\end{tabular}


Exhibit B-2

SUMMARY OF PROPOSAL (item 2; not to exceed one page) 
Exhibit B-2

DESCRIPTION OF PROJECT (item 3; not to exceed 10 pages)

E-14 
REFERENCES (item 4)

EQUIPMENT (item 5)

BIOGRAPHICAL INFORMATION (item 6)

REVIEWERS (item 7) 
INFORMATION ABOUT THE PROPOSAL (item 8)

1. HUMAN SUBJECTS (Reference: DOE Order 1300.3)

Are human subjects involved from BNL or a collaborating institution?

If yes, attach copy of the current Institutional Review Board

Approval and Informed Consent Form from BNL and/or

collaborating institution.

$\mathrm{Y} / \mathrm{N}$

\section{VERTEBRATE ANIMALS}

Are vertebrate animals involved?

If yes, has approval from BNL's Animal Care and Use

Committee been obtained?

$\mathrm{Y} / \mathrm{N}$

$\mathrm{Y} / \mathrm{N}$

\section{NEPA REVIEW}

Are the activities proposed similar to those now carried out in the Department/Division which have been previously reviewed for potential environmental impacts and compliance with federal, state, local rules and regulations, and BNL's Environment, Safety, and Health Standards? (Therefore, if funded, proposed activities would require no additional environmental evaluation.)

$\mathrm{Y} / \mathrm{N}$

If no, has a NEPA review been completed in accordance with the Subject Area National Environmental Policy Act (NEPA) and Cultural Resources Evaluation and the results documented?

$\mathrm{Y} / \mathrm{N}$

(Note: If a NEPA review has not been completed, submit a copy of the work proposal to the BNL NEPA Coordinator for review. No work may commence until the review is completed and documented.)

\section{ES\&H CONSIDERATIONS}

Does the proposal provide sufficient funding for appropriate decommissioning of the research space when the experiment is complete?

$\mathrm{Y} / \mathrm{N}$

Is there an available waste disposal path for project wastes throughout the course of the experiment?

$\mathrm{Y} / \mathrm{N}$

Is funding available to properly dispose of project wastes throughout the course of the experiment?

$\mathrm{Y} / \mathrm{N}$

Are biohazards involved in the proposed work? If yes, attach a current copy of approval from the Institutional Biosafety Committee.

$\mathrm{Y} / \mathrm{N}$

Can the proposed work be carried out within the existing safety envelope of the facility (Facility Use Agreement, Nuclear Facility Authorization Agreement, Accelerator Safety Envelope, etc.) in which it will be performed? 
If no, attach a statement indicating what has to be done and how modifications will be funded to prepare the facility to accept the work.

5. TYPE OF WORK

Select Basic, Applied

\section{LINK TO LABORATORY STRATEGIC INITIATIVES}

Identify below which energy-related $\mathrm{R} \& \mathrm{D}$ area your proposal supports, http://www.bnl.gov/ldrd/FY08_EnergyRelated_LDRD/

\section{POTENTIAL FUTURE FUNDING}

Identify below the Agencies and the specific program/office, which may be interested in supplying future funding. Give some indication of time frame.

\section{APPROVALS}

Department /Division Administrator

Print Name

Department Chair/Division Manager

Print Name

Cognizant Associate Director

Print Name 
BUDGET REQUEST BY FISCAL YEAR (item 9)

Exhibit B-2

Department
Title
PI

(Note: Funding duration cannot exceed 36 months.)

\begin{tabular}{|c|c|c|c|c|c|}
\hline COST ELEMENT & $\begin{array}{l}\text { FISCAL } \\
\text { YEAR }\end{array}$ & $\begin{array}{l}\text { FISCAL } \\
\text { YEAR }\end{array}$ & $\begin{array}{l}\text { FISCAL } \\
\text { YEAR }\end{array}$ & $\begin{array}{l}\text { FISCAL } \\
\text { YEAR }\end{array}$ & $\begin{array}{l}\text { TOTAL } \\
\text { COST }\end{array}$ \\
\hline $\begin{array}{l}\text { Labor* } \\
\text { Fringe } \\
\quad \text { Total Labor } \\
\text { Organizational Burden @___ \% }\end{array}$ & & & & & \\
\hline DISTRIBUTED TECHNICAL SERVICES & & & & & \\
\hline $\begin{array}{l}\text { Materials } \\
\text { Supplies } \\
\text { Travel } \\
\text { Services } \\
\quad \text { Total MST } \\
\text { Materials Burden @ _ } \%\end{array}$ & & & & & \\
\hline $\begin{array}{l}\text { TECHNICAL COLLABORATORS/ } \\
\text { CONSULTANTS }\end{array}$ & & & & & \\
\hline $\begin{array}{l}\text { Sub-contracts } \\
\text { Contracts Burden @ _ } \%\end{array}$ & & & & & \\
\hline $\begin{array}{l}\text { Electric Power } \\
\text { Other (specify) }\end{array}$ & & & & & \\
\hline $\begin{array}{l}\text { Traditional G\&A @ _ } \% \\
\text { Common Support G\&A @__ } \%\end{array}$ & & & & & \\
\hline TOTAL PROJECT COST & & & & & \\
\hline $\begin{array}{l}\text { *Labor (give levels of effort with names, or if unkno } \\
\text { indicate TBD) } \\
\text { Scientific \& Professional } \\
\text { Post Doc } \\
\text { Other }\end{array}$ & & & & & \\
\hline $\begin{array}{l}\text { Note: } \\
\text { The Budget Office covers } 20 \% \text { of the Post Doc's } \\
\text { salary/fringe. }\end{array}$ & & & & & \\
\hline $\begin{array}{l}\text { List all Materials and Equipment Costing Over } \\
\$ 5000\end{array}$ & & & & & \\
\hline
\end{tabular}


Exhibit C

\section{LDRD DATA COLLECTION FORM}

Read and then remove the instructions before completing this form; return it electronically to Sabrina Parrish (sabrina@bnl.gov)

\section{LDRD PROJECT NUMBER:}

PROJECT TITLE:

PRINCIPAL INVESTIGATOR (S):

PUBLICATIONS

TOTAL

List all refereed publications originating in whole or in part from this LDRD, during the fiscal year, including those that have been submitted, but do not include any that are in preparation. Provide the total number above.

MEETINGS, PROCEEDINGS, AND ABSTRACTS TOTAL

List all formal presentations originating in whole or in part from this LDRD presented during the fiscal year. Provide the total number above.

\section{REPORTS}

TOTAL

List all formal reports originating in whole or in part from this LDRD including those that have been published during the fiscal year. Provide the total number above.

\section{PATENTS AND LICENSES}

TOTAL

List all patents and licenses originating in whole or in part from this LDRD during the fiscal year. Provide the total number above.

\section{COPYRIGHTS} TOTAL

List all copyrights (other than publications) originating in whole or in part from this LDRD granted during the fiscal year. Provide the total number above.

\section{INVENTION DISCLOSURES}

TOTAL

List all invention disclosures submitted during the fiscal year to the Laboratory's Office of Intellectual Property \& Sponsored Research that were either directly derived from this LDRD or from any follow-on efforts. Provide the total number above. 
List all formal review presentations that pertain to this work conducted during the fiscal year. Include the name of the reviewing body and date of review, title of presentation, and names of presenters. Provide the total number above. Do not include the mid-year LDRD program reviews.

STUDENTS AND RESEARCH ASSOCIATES TOTAL

Provide names of all graduate students and Research Associates supported during the fiscal year and give the number of months that they were supported. Provide the total number above combined as full-time equivalents, rounded to the nearest month.

NEW HIRES

TOTAL

Provide names of any new staff who were hired during the fiscal year as a direct result of this LDRD. Provide the total number above.

FOLLOW-ON FUNDING

TOTAL

List all requests for funding submitted during the current and prior fiscal years including any that have been rejected. Give the title of the project, the Principal Investigator, date of submission, the name of the agency, action taken, amount funded or requested per year, and the duration. Provide the total number above.

AWARDS

TOTAL

Provide information on any national awards or recognitions received during the fiscal year that are attributable in whole or in part to the LDRD project. For each award, describe (in 150 words or less) its significance and the role that LDRD played in achieving it. Provide the total number above. 
date:

May 9, 2007

to:

Distribution

from:

L. Newman L.S.

subject:

FY 2008 LDRD Proposals for Review

We are about to enter the important process of selecting LDRD projects for support in the next fiscal year. All of you will be asked to rate the proposals and participate in the discussions. However, only the ALDs will be involved in the final selection. As different from the past, I will serve solely as the facilitator and not participate in the rating process.

We have received 62 proposals in good order. Attached please find a table listing all of the proposals and a complete set of abstracts. The ALD, as the most qualified expert, will serve as the first proponent for all proposals in his Directorate. This is already indicated as, $1 \mathrm{P}$, in the table. In addition, the ALDs will serve as second proponents (2P) for approximately one quarter of the remaining proposals. There are five scientists from the Brookhaven Council who will also serve as second proponents, each to approximately one fifth of the proposals.

In order to assign to each of you the proposals that you will feel most comfortable with reviewing, I request that on the attached table you indicate those proposals for potential review that you are highly interested in $(\mathrm{H})$, moderately interested in $(\mathrm{M})$, or have no interest in $(\mathrm{N})$. The Brookhaven Council members should recuse themselves and designate by an $\mathrm{R}$, from all proposals for which they might have a conflict of interest, such as being a Co-PI or collaborator. Email your selections to me (newman@bnl.gov) by May 18 and I will do my best to comply with your wishes in the assignment process.

We will then provide you with copies of all those proposals that you have been assigned, but as we assume that the ALDs have copies of the proposals in their Directorates, we will not send them any of those. All proposals will be available to you at http://intranet.bnl.gov/ldrd/FY08-proposals/ through which they were submitted, if you wish to be more fully informed on a particular proposal. Prior to the onset of the first meeting, you will be asked to provide your initial ratings for all proposals for which you are a proponent. The ALD for Policy and Planning will have read all the proposals prior to the meeting and will have also provided ratings as a third proponent. We will be using a rating process consisting of: highest priority (4), high priority (3), fund if possible (2), or low priority (1) and we request that you only use integers when making your ratings. Please remember when deciding upon your ratings that we will only be able to fund a small fraction of the proposals.

We will ask for consensus to eliminate, without discussion, those proposals that have fared so poorly in the initial rating that they are deemed unlikely to be selected for funding (functionally, this would be for proposals with an average score of 2.5 or lower.) Any ALD can request that any proposal that faired poorly be included for consideration in the discussion and selection process.

Once the poorly rated proposals have been eliminated, we will then embark upon discussions of each of the remaining proposals, led by the principal proponent with augmentation by the two second proponents, 
upon which all of you will be asked to provide ratings. In the discussion of the remaining proposals, the following criteria are to be used to frame discussions and base ratings:

- The intellectual merit of the proposed activity:

How important is the proposed activity to advancing knowledge and understanding within its own field or across different fields?

To what extent does the proposed activity suggest and explore creative and original concepts?

Are the proponent(s) qualified to conduct the proposed research?

How well-conceived and organized is the proposed activity?

Is there sufficient access to resources? Is the scope of work commensurate with the requested budget?

- The broader impacts of the proposed activity:

Will the activity lead to new capabilities or competencies at the Laboratory?

Will this project help to ensure the scientific and technical vitality of the Laboratory?

Does the proposal foster cross disciplinary and/or cross Organizational Unit collaborations?

Does the proposal appropriately anticipate DOE or other sponsor needs? How can one tell?

If you need any clarification, please feel free to contact me or Sabrina Parrish.

$\mathrm{LN} / \mathrm{sp}$

Table and Abstracts attachments

Distribution: ALDs, Council Scientists, J. P. Looney

cc: N. Narain, K. Fox, K. Barkigia 
BNL: Departments | Science | ESS\&H | Newsroom | Administration | Visitors | Directory

search

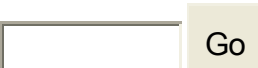

Site Details

LDRD Home

FY08 Energy Related

\section{LDRD}

Current Schedule

Proposal Submission

Subject Area

DOE Order O413.2B

DOE-SC Roles \&

Responsibilities

Guidance dated 6/13/06

$\underline{(p d f)}$

LDRD Reports (PDFs)

View Reports

Other Information

BNL Site Index

Can't View PDFs?
Focus Areas for FY08 LDRD Funding in Support of BNL's Scientific Agenda

\section{Call for LDRD Proposals in Energy-related Research and Development}

The solicitation is closed for FY-2008 energy-related proposals- click here

We are now soliciting proposals for the annual LDRD competition for awards that will begin in Fiscal Year 2008 (FY08). It is anticipated that new LDRDs will begin funding on January 1, 2008, barring any significant issues with the Congressional budget process.

It is important to note that for FY08 there will be two different calls for proposals. The first call, issued in March 2007, is an open call for proposals. The second call, to be issued in the late spring or early summer of 2007, will be a focused call for proposals in energy related R\&D in support of the Lab's strategic plan in energy R\&D. Proposals that specifically support the Laboratory's strategic plan in energy research should not be submitted in response to the first (general) call. In the general call, all proposals for innovative research 
that could lead to break-through science in areas that advance the mission of the Laboratory are encouraged (with the exception of proposals in support of the Lab's energy strategy). The deadline for receipt of proposals for this call is COB April 30, 2007. As requested in the $P I Q$, proposals should identify potential follow-on sponsors and likelihood of funding, assuming the proposed project were to be successful.

As a part of this call, proposals which support the Laboratory's Strategic Initiatives are especially encouraged. For FY08, the focus areas which support the strategic agenda are:

\section{Research in Light Source Instrumentation and}

Techniques - Research in advanced concepts and instrumentation with the potential to expand the capabilities of BNL's Light Sources (present, planned, and possible future) which might lead to a new technique, substantial improvement(s) to existing technique(s), or to development of new, advanced instrumentation and/or sources. Proposals that establish ties between Laboratory programs and the Light Sources are of particular interest.

Evolution of RHIC to a QCD Lab - Research that supports the Laboratory's vision to develop a QCD Laboratory at RHIC, with a particular emphasis on projects focused on research in the physics of the electron-ion collider; the physics opportunities enabled by the electron-ion collider, machine and detector concepts studies, proof of concept experiments, etc. 
Computational Science - The 100Tflop SBU/BNL BlueGene/L (BG/L) computer is an outstanding resource that will soon be available to BNL scientists. This year, we encourage projects to begin to utilize this machine. Proposals to migrate current computation efforts to BG/L and/or new efforts that expand the range of scientific applications that would run on the BG/L computer are of particular interest.

Energy - The subject of a second call for proposals to be issued in the late spring or early summer of 2007 will be in support of the Lab's strategic plan in Energy R\&D. The areas for the Energy R\&D call are anticipated to be Biofuels, Solar Energy, Advanced Materials, Catalysis, and Nuclear Energy. The focus of this call will be the "white papers" in these areas that are currently under development by the energy strategy committee chaired by Doon Gibbs.

A Top

\section{Program Description}

The purpose of the Laboratory Directed Research and Development (LDRD) Program is to promote the conduct of highly innovative and exploratory research that fits into the mission of the Laboratory including strategic initiatives for the growth of the Laboratory. The Laboratory mission areas include advancements in physics, chemistry, and biology, and in medical, energy and environmental sciences, and in the utilization of the 
user facilities that include accelerators for particles, heavy ions, and synchrotron light. The following is a list of the general principles that guide the LDRD Program.

- Fund highly innovative and exploratory research that can be of high risk.

- Expect high payoff such as funding prospects, breakthrough science and broadening of the Laboratory's mission.

- Set a fraction of the funds for strategic areas.

- Give some preference to emerging scientists consistent with the quality of their proposals.

- Collaborations across Directorates and Departments should be encouraged.

- Successful organization and execution of each approved proposal is the responsibility of an appointed Associate Laboratory Director (ALD) in the area of activity.

- ALDs as a group with the benefit of ratings from a committee make the final selections for the Laboratory-Wide Competition.

- Do not use the LDRD process as a way to support unfunded investigators.

- Track the productivity and success of funded proposals.

- Support stops if you obtain funding elsewhere.

\section{Program Structure}

The program has two categories, the annual competed LDRDs and Strategic LDRDs, which combine to meet the overall objective of the LDRD Program.

\section{Competed LDRD Proposals}

Proposals are solicited annually for review and approval concurrent with the next fiscal year, October 1. An LDRD Selection Committee, comprised of the Associate 
Laboratory Directors (ALDs) for the Scientific

Directorates, an equal number of scientists recommended by the Science Council, plus the LDRD Scientific Director, and the Assistant Laboratory Director for Policy and Planning, review the proposals submitted in response to the solicitation.

The competed LDRD category emphasizes innovative research concepts with limited management filtering to encourage the creativity of individual researchers. The competition is open to all BNL staff in programmatic, scientific, engineering, and technical support areas. Researchers submit their project proposals to the LDRD Scientific Director.

\section{Strategic LDRD Proposals}

A portion of the LDRD budget is held for the Strategic LDRD (S-LDRD) category. These funds are used to establish and enhance initiatives that are consistent with Laboratory priorities. Projects in this category focus on innovative R\&D activities that are likely to develop new programmatic areas within BNL's mission responsibilities and enhance the Laboratory's science and technology base. The Laboratory Director entertains requests or articulates the need for S-LDRD funds at any time. The Director selects two people to provide written reviews of the proposals.

These Projects are driven by special opportunities, including: 
- Research project(s) in support of a Laboratory strategic hire,

- Evolution of Program Development activities into research and development activities,

- ALD proposal(s) to the Director to support unique research opportunities,

- Research project(s) in support of Laboratory strategic initiatives as defined and articulated by the Director.

\section{Administration}

Further information and assistance can be obtained from Leonard Newman, Scientific Director for LDRD, either by email (Idrd@bnl.gov ) or telephone (ext. 4467), or Kevin Fox, Special Assistant to the ALD for Finance, email Idrd@bnl.gov or telephone (ext. 6185).

Documentation on all approved LDRD projects is maintained by the LDRD Program to assure that projects have undergone proper review and are in compliance with all applicable requirements.

\section{Exhibits}

- Data Collection Form

- PIQ Form

- Sample Interim Status Report

\section{LDRD Program Data}

- FY 02 List of Funded Projects (PDF)

- FY 03 List of Funded Projects (PDF)

- FY 04 List of Funded Projects (PDF)

- FY 05 List of Funded Projects (PDF)

- FY 06 List of Funded Projects (PDF)

- FY 07 List of Funded Projects (PDF)

- FY 08 List of Funded Projects (PDF) 
Exhibit E

Note: Depending on your browser configuration, PDF

files may not open as expected. If you see a blank page

or have other problems viewing these PDF files, see the

list of common solutions.

Last Modified: October 12, 2007

Please forward all questions about this site to: Sabrina

Parrish

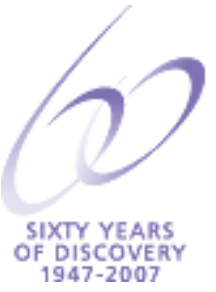

One of ten national laboratories overseen and primarily funded by the Office of Science of the U.S. Department of Energy (DOE), Brookhaven National Laboratory conducts research in the physical, biomedical, and environmental sciences, as well as in energy technologies and national security. Brookhaven Lab also builds and operates major scientific facilities available to university, industry and government researchers. Brookhaven is operated and managed for DOE's Office of Science by Brookhaven Science Associates, a limited-liability company founded by Stony Brook University, the largest academic user of Laboratory facilities, and Battelle, a nonprofit, applied science and technology organization.

Privacy and Security Notice I Contact Web Services for help 


\section{Subject Area: Laboratory Directed Research and Development (LDRD) Program}

\section{VIEW/PRINT ALL (No Exhibits and Forms)}

\begin{tabular}{l|l|l} 
Effective Date: Nov 4, 2004 & (Rev 3.7) \\
Periodic Review Due: Nov 4, 2009 & $\begin{array}{l}\text { Subject Matter Expert: } \\
\text { Kevin Fox }\end{array}$ & $\begin{array}{l}\text { Management System Steward: } \\
\text { Doon Gibbs }\end{array}$
\end{tabular}

\section{Introduction}

This subject area describes the procedures for preparing, submitting, reviewing, and approving proposals for the Laboratory Directed Research and Development (LDRD) Program. It also describes the procedures for reporting on the status of LDRD projects.

The purpose of the LDRD Program is to encourage and support the development of ideas that could lead to new programs, projects, and directions for the Laboratory. The LDRD program focuses on early exploration and exploitation of creative and innovative concepts, which enhance the ability of the Laboratory to carry out its current and future mission objectives in line with the goals of the Department of Energy (DOE). This discretionary research and development tool is viewed as one important way of maintaining the scientific excellence of the Laboratory. It is a means to stimulate the scientific-technological community (foster new science and technology ideas), which is a factor in achieving and maintaining staff excellence, and is a means to address national needs within the overall mission of the DOE.

The LDRD program includes all discretionary research and development activities other than those provided for in a DOE/NNSA program or by specific designation in the Prime Contract. The LDRD program includes all discretionary research and development activities other than those provided for in a DOE/NNSA program or by specific designation in the Prime Contract.

\section{Program Structure}

The program consists of two categories, Competed LDRDs and Strategic LDRDs which, combined, meet the overall objectives of the LDRD Program.

\section{Competed LDRD Proposals}

Proposals are solicited annually for review and approval concurrent with the start of the next fiscal year, October 1. An LDRD Selection Committee, comprised of the Associate Laboratory Directors (ALD) for the Scientific Directorates, an equal number of scientists recommended by the BNL Council, plus the LDRD Scientific Director, and the Assistant 
Laboratory Director for Policy and Planning, review the proposals submitted in response to the solicitation.

The competed LDRD category emphasizes innovative research concepts with limited management filtering to encourage the creativity of individual researchers. The competition is open to all BNL staff in programmatic, scientific, engineering, and technical support areas. Researchers submit their project proposals to the LDRD Scientific Director.

\section{Strategic LDRD Proposals}

A portion of the LDRD budget is held for the Strategic LDRD (S-LDRD) category.. These funds are used to establish and enhance initiatives that are consistent with Laboratory priorities. Projects in this category focus on innovative R\&D activities that are likely to develop new programmatic areas within BNL's mission responsibilities and enhance the Laboratory's science and technology base. The Laboratory Director entertains requests or articulates the need for S-LDRD funds at any time.

These Projects are driven by special opportunities, including:

- Research project(s) in support of a laboratory strategic hire

- Evolution of Program Development activities into research and development activities

- ALD proposal(s) to the Director to support unique research opportunities

- Research project(s) in support of laboratory strategic initiatives as defined and articulated by the Director

\section{Contents}

\section{Section}

1. Preparing, Submitting, Reviewing, and Approving Competed LDRD Proposals

2. Preparing, Submitting, Reviewing, and Approving Strategic LDRD Proposals

3. Preparing and Submitting Reports on LDRD Projects

Definitions

\section{Exhibits}

\section{Overview of Content (see section for full process)}

- Complete Proposal Information Questionnaire.

- Review and approve proposals.

- Authorize funding.

- Complete Proposal Information Questionnaire.

- Review and approve proposals.

- Authorize funding.

- Submit status reports. 
Examples of Projects for LDRD Funding

Exhibit F

Restrictions on LDRD Awards

Sample Interim Status Report

\section{Forms}

LDRD Data Collection Form

Proposal Information Questionnaire

Strategic LDRD Proposal Review with Instructions

\section{Training Requirements and Reporting Obligations}

This subject area does not contain training requirements.

This subject area contains the following reporting obligations:

- Principal Investigators (PIs) submit an annual status report by November 1 to the LDRD Scientific Director.

- PIs present an Annual LDRD Mid-year Project Review.

- For each year that the program is active and for two years after the completion of the project, PIs submit a LDRD Data Collection Form to the LDRD Scientific Director.

- LDRD Scientific Director submits an Annual Program Plan to the DOE BHSO by August 15

- LDRD Scientific Director submits an Annual Report to the DOE BHSO by March 31

- LDRD Scientific Director annually submits Project Data Sheets to the DOE BHSO by August 31

- LDRD Scientific Director annually submits the required information to OMBE/CFO Database

- LDRD Scientific Director annually submits to DOE Laboratory Policy Division data for Congressional report

- LDRD Scientific Director annually submits performance indicators data to DOE Laboratory Policy Division

See the section Preparing and Submitting Reports on LDRD Projects.

\section{External/Internal Requirements}

\begin{tabular}{|l|l|}
\hline \multicolumn{1}{|c|}{ Requirement Number } & \multicolumn{1}{c|}{ Requirement Title } \\
\hline$\underline{\text { BSA Contract No. DE-AC02-98CH10886- }}$ & Statement of Work \\
\hline$\underline{\text { Clause C.4 }}$ & $\begin{array}{l}\text { Laboratory Directed Research and } \\
\text { Development }\end{array}$ \\
\hline$\underline{\mathrm{O} 413.2 \mathrm{~B}}$ & \\
\hline
\end{tabular}

\section{References}

Laboratory Directed Research and Development (LDRD) Web site 


\section{Standards of Performance}

Provide for strategic growth and investment in the Laboratory's programmatic mission and supporting assets through the following:

- Using Laboratory Directed Research and Development (LDRD);

- Maintaining an Annual Laboratory Plan through a process for formal strategic planning; and

- Maintaining a supportive work environment that fosters innovative scientific and technological research and analysis to serve customers needs, and staff development to address long-term organizational needs and staff career goals.

All staff shall ensure that the scientific and technical information resulting from BNL research is available to the maximum permissible extent for future use by the scientific community and the public within BNL's and the customer's requirements.

The only official copy of this file is the one on-line in SBMS.

Before using a printed copy, verify that it is the most current version by checking the effective date. | SBMS Home Page | Subject Areas | Instructions | Revision History | 


\section{Monday Memo Article Volume 9 - Number 7}

Exhibit G

\section{SOLICITATION FOR FY08 LDRD PROPOSALS - Leonard Newman}

The annual call for proposals for the Laboratory-Directed Research and Development (LDRD) competition has been released. I would like to encourage all scientists to send in their proposals. As I've mentioned in past Monday Memos, research conducted under the LDRD program should be highly innovative, and an element of high risk as to success is acceptable.

While the LDRD award selection process will be essentially the same as in past years, there are notable changes in the program this year. For FY08, we anticipate that we will be able to fund some projects aimed at the development of new core competencies at BNL at somewhat higher levels than in the past, with budgets funded for a full 36 months. The business case, including the potential for follow-on funding for proposals in this "competence building" class of proposals will be held to a high standard.

As a part of this call, proposals that support the Laboratory's strategic initiatives (www.bnl.gov/ldrd) are especially encouraged. However, in one strategic area we will follow a different path. As you may be aware, the Laboratory has undertaken an effort to develop a vision and strategy for research and development in energy sciences. This strategy capitalizes on several of the Laboratory's core competencies and facilities and will help define the activities in this area at Brookhaven for the foreseeable future. Consequently, we will be issuing a separate call focused on energy-related proposals later this spring or early in the summer, once the Science \& Technology Steering Committee has completed its review of the strategy.

At this time, we anticipate that the areas for the energy strategy call will be biofuels, solar energy, advanced materials, catalysis, and nuclear energy. The focus of the call for energy proposals will be the "white papers" in these areas that are currently under development by an energy strategy committee chaired by Doon Gibbs. Proposals that specifically support the Laboratory's strategic plan in energy research should not be submitted in response to this call. Further information will be given in the call for those proposals at a later date.

The deadline for receipt of proposals is close-of-business on April 30, 2007. We ask that you submit your proposal electronically through your respective chairperson/division head and ALD to Sabrina Parrish (LDRD@bnl.gov). In addition, please submit the current version of the proposal information questionnaire (PIQ) form. I am available to aid individuals in the preparation of a proposal and to answer any questions you may have regarding the LDRD program.

As the Congressional budget process has not concluded on-time in the past 12 years, we believe that it is best to plan for funding of new FY08 LDRD projects to begin on January 1, 2008; unless the potential exists at that time for a significant budgetary impact to the Laboratory arising from the appropriations process (which has been the case the last two years).

As usual, research conducted under the LDRD program may not duplicate or directly augment research presently funded at the Lab. The policy and guidelines for the BNL LDRD program are posted here.

- Leonard Newman

Scientific Director, LDRD program

newman@bnl.gov 
(08-001) How Does Color Flow in a Large Nucleus: Exploring the Chromo-Dynamics of QCD through Diffractive and Jet Measurements at eRHIC

Will focus on understanding the chromodynamics of two processes in deeply inelastic scattering off nuclei at high energies: a) diffraction and b) jet production.

(08-002) Strongly Correlated Systems: from Graphene to Quark-Gluon Plasma
D. Kharzeev
(FY 2008 Funding \$127,000)

Advance the quantitative description of the properties of strongly coupled quark-gluon plasma and provide qualitatively new insights into the dynamics of heavy ion collisions at RHIC. We plan to investigate the equation of state of quark-gluon plasma using the methods of nonperturbative QCD and of condensed matter physics, and to understand better the restoration of chiral symmetry in strongly coupled quark-gluon plasma, analogous to the disappearance of excitonic condensate in graphene.

(08-004) Getting to Know Your Constituents: Studies of Partonic Matter at the EIC W. Vogelsang

(FY 2008 Funding \$115,200)

Set up and commission a robust framework that provides practical ways of extracting information on the quark and gluon structure of the proton and of nuclei from future Electron-Ion Collider (EIC).

(08-005) Development of the Deuteron EDM Proposal Y. Semertzidis

(FY 2008 Funding \$320,100)

The storage ring EDM Collaboration (SREC) has presented an LOI for a sensitive deuteron EDM (dEDM) experiment at BNL to the RHIC/AGS Physics Advisory Committee. Plan to investigate the systematic errors associated with the storage ring method, those regarding the deuteron polarimeter $(\$ 300 \mathrm{~K})$ will cover incremental cost for consumables and travel support for the US groups involved on it.

(08-008) Development of a Small Gap magnets and Vacuum Chamber for eRHIC V. Litvinenko

(FY 2008 Funding \$120,000)

Propose to test the quality of mini-gap (gaps $\sim 5 \mathrm{~mm}$ ) dipole and quadrupole magnets with a common vacuum chamber for 4 passes around the RHIC and to verify that quality of magnetic field is compatible with high beam quality and stable beam dynamics in eRHIC. 
A major limitation of macromolecular crystallography is the failure to obtain large enough crystals for traditional diffraction studies at the NSLS. Propose to address this critical gap. Will develop protocols to determined structures from microcrystals. (Grid-Search) will locate microcrystals on a two-dimensional grid supporting a suspension of cryopreserved microscrystals

(08-025) Combined PET/MRI Multimodality Imaging Probe

$$
\text { D. Schlyer (FY } 2008 \text { Funding \$204,000) }
$$

Design a multimodal imaging probe for use with our combined MRI-PET animal imaging system with will allow simultaneous PET and MRI measurements.

(08-028) Genomic DNA Methylation: The Epigenetic Response of Arabidopsis thaliana Genome to Long-Term Elevated Atmospheric Temperature and $\mathrm{CO}_{2} \underline{\text { in Global }}$ Warming

Q. Liu

(FY 2008 Funding \$130,000)

Will evaluate the epigenetic response of plants that is likely to occur in response to the elevated atmospheric temperatures and $\mathrm{CO}_{2}$ level. Will use a plant model organism, Arabidopsis thaliana to understand the gene expression changes that are epigenetically controlled by DNA methylation to response to global warming. Will use two complementary approaches: (1) Microarray analysis to identify changes in the overall gene expression profile. (2) Genomic methylation profiling to identify genes whose expressions are altered due to methylation or demethylation of cytosine in their coding or regulatory sequence regions.

(08-034) Fabry-Perot Interferometer \& Hard X-ray Photoemission
E. Vescovo
(FY 2008 Funding \$90,000)

Propose to manufacture a Farby-Perot (FP) etalon by micro-etching techniques on a single crystal Si wafer. Aim at designing an interferometer with less sharp resonances ( $\sim 10 \mathrm{meV}$ ) distributed over a larger energy range $(\sim 1 \mathrm{eV})$.

(08-037) Ultrafast Electron Diffraction for Transient Structure and Phase Transition Studies at the NSLS SDL

X. Wang

(FY 2008 Funding \$90,000)

Propose to developcompact ultrafast electron diffraction (UED) at the NSLS SDL. Will employ a photocathode RF gun to generate 1 to $4 \mathrm{MeV}$ electrons; capable of reaching 100 fs time resolution with about 1 million electrons. 
Will allow the establishment of a new laser-based photoemission facility with variable light polarization that will be used in studies of strongly correlated electron systems. Coupled to a new electron spectrometer this facility will also serve as a test bed for new approaches to time resolved electron spectroscopies at storage rings including the future NSLS II.

(08-042) Theory of Electronic Excited States in Heterogeneous Nanosystems
M. S. Hybertsen
(FY 2008 Funding \$107,000)

Proposed an approximate approach to calculate electronic excitation energies, based on an established theoretical framework. Contains essential physical processes that determine electronic excitation energies in heterogeneous nanosystems, but it could be significantly more efficient. Systematic analysis of the approach will be performed with applications to prototype materials to test the accuracy.

(08-043) Nanofrabrication Methods Using Solution-Phase Nanomaterials
C. Black
(FY 2008 Funding \$120,000)

Will create an innovative and wide-ranging nanofrabrication technique for building functional solid-state structures from solution-phase nanomaterials, and then explore the technique's utility through device demonstrations. Develop a unique new fabrication method for uniform largearea assembly of solution-phase nanomaterials; to fabricate devices for studying photogenerated carrier transport in semiconductor nanocrystals; and to investigate one-dimensional electronic wire structures fabricated from solution-phase nanocrystals.

(08-051) Identification of Organic Aerosols and Their Effects on Radiative Forcing Y.-N. Lee (FY 2008 Funding \$126,000)

Develop an electrospray ionization-mass spectrometry (ESI-MS) based technique in combination with size-exclusion chromatography (SEC) and total organic carbon (TOC) analysis for identification and quantification of high molecular weight organic compounds in ambient aerosol particle to gain insights into their sources, formation and radiative effects. Proposed technique consists of three components: separation, identification and quantification.

(08-060) Computational Climate Science

$$
\text { A. Vogelmann }
$$

(FY 2008 Funding \$187,000)

Will use the tropics as a convection test bed to determine whether explicit vs. parameterized convection treatments are needed in global climate models to accurately simulate convection and aerosol transport. Simulations will be run on Blue Gene/L (BG) supercomputer with successively high resolutions, and will be validated using newly available satellite observations and observational techniques determine and target the most deficient physical processes by exploiting BG computational power to map the variances of the model solutions in a phase space that considers the uncertainties in the model parameters and boundary conditions, especially those associated with convection. 
(08-062) A Novel Spintronic Room-Temperature High Purity Germanium X- and GammaRay Spectrometer

A. Bolotnikov/G. Camarda

(FY 2008 Funding \$116,000)

A new spintronic high-purity germanium gamma-ray detector concept is proposed. Spintronic devices are based on the manipulation of an electron's spin state in addition to its charge, and have the potential to result in order-of-magnitude scale improvements in the performance of various semiconductor devices.

(08-080) Tracer Development - Improving PET and MR Imaging

$$
\text { J. S. Fowler (FY } 2008 \text { Funding \$1,156,000) }
$$

The goal is to develop new classes of markers for medical imaging including development of new targeting strategies to increase the specificity of imaging, and the development of new types of tracers such as tagged nanoparticles, and quantum dots.

(08-081) New MR Technology for Studies of Human Biology

$$
\text { F. Henn (FY } 2008 \text { Funding \$1,235,000) }
$$

This proposal is aimed at developing new ways of using MRS to measure specific cells as well as specific neurotransmitters over time in vivo in the CNS of animals and people. An additional project aims to use TMS to simulate deep brain circuits which can then be mapped by fMRI. 


\section{Relatedness to Laboratory Initiatives by Project}

\section{Project} Number

Number

\section{NSLS-II}

06-046 Novel Materials for Hard X-Ray Optics

06-047 Nano-Crystallography of Individual Nanotubes and Nanoparticles

08-022 Novel Methods for Microcrystal Structure Determination at NSLS and NSLS-II

08-034 Fabry-Perot Interferometer \& Hard X-ray Photoemission

08-039 The Development of a Laser Based Photoemission Facility for Studies of Strongly

\section{Evolution of RHIC to a QCDLab}

07-006 Feasibility and Design Studies for a Detector for e+p, e+A, p+p, p+A, and A+A Collisions at BNL

07-007 A Novel and Compact Muon Telescope Detector for QCD Lab

07-019 Development of Laser Beam Shaper for Low Emittance Electron Beams

07-097 Polarized Electron SRF Gun

08-001 How Does Color Flow in a Large Nucleus: Exploring the Chromo-Dynamics of QCD through Diffractive and Jet Measurements at eRHIC

08-002 Strongly Correlated Systems: From Graphene to Quark-Gluon Plasma

08-004 Getting to Know Your Constituents: Studies of Partonic Matter at the EIC

08-008 Development of a Small Gap Magnets and Vacuum Chamber for eRHIC

\section{Nanoscience}

06-012 Detector for High Quality Images of Electron Microscopy

06-021 Synthesis and Characterization of Band-Gap-Narrowed TiO2 Thin Films and Nanoparticles for Solar Energy Conversion

06-037 Electronic Properties of Carbon Nanotubes and Novel Multicomponent Nanomaterials

06-047 Nano-Crystallography of Individual Nanotubes and Nanoparticles

06-092 Nanoparticle Labeled Neural Stem Cell Tracking In Vivo by Magnetic Resonance Microscopy

07-023 Surface Engineered and Core-Shell Nanowires: Nanoscale Building Blocks for Third Generation Photovoltaics

07-025 Precision Assembly of Nano-Objects - Approaching Artificial Photosynthesis

07-030 Structure of Mass-Size Selected Nanoparticles by Scanning Transmission Electron

07-036 Lipid-Coated Nanoparticles and Their Interactions with Lipid Membrane Surfaces

07-038 Angle-Resolved Time-of-Flight Ion Scattering Spectroscopy from MBE-Grown Oxide Thin Film Surfaces 
07-062

08-042 Theory of Electronic Excited States in Heterogeneous Nanosystems

08-043 Nanofabrication Methods using Solution-Phase Nanomaterials

\section{Energy}

06-021

Synthesis and Characterization of Band-Gap-Narrowed TiO2 Thin Films and Nanoparticles for Solar Energy Conversion

06-061 Diversification of Isoflavonoid Biosynthesis

06-097 Photocatalytic Reduction of CO2 in Supercritical CO2

07-023 Surface Engineered and Core-Shell Nanowires: Nanoscale Building Blocks for Third Generation Photovoltaics

07-025 Precision Assembly of Nano-Objects - Approaching Artificial Photosynthesis

07-027 Photocatalytic Carbon Dioxide Reduction to Methanol using Metal Complexes with an NADH Model Ligand

07-032 Synthesis of Conjugated Polymers for Fundamental Questions in Solar Energy

07-035 Ultra-thin Graphite Analog Compounds

07-047 Characterization of Enzymatic O-acylation to Facilitate Biomass and Bioenergy Production

07-059 A Non-Fermentation Route to Convert Biomass to Bioalcohols

07-080 A Novel Approach for Efficient Biofuel Generation

07-098 New Approach to H Production, Stages and use

\section{Computational Science}

07-002 Lattice QCD Simulations on BlueGene/L

07-101 High End Scientific Computing

08-042 Theory of Electronic Excited States in Heterogeneous Nanosystems

08-060 Computational Climate Science

\section{Imaging}

06-094

MicroCT Methods of Quantitative Adipose Imaging: Development of a Long-Term Assessment Technique for Studying Obesity in a Rodent Model

07-048 Functional Neurochemistry

07-054 Miniaturized RF Coil Arrays for MicroMRI

07-055 Neurocomputation at BCTN: Developing Novel Computational Techniques to Study Brain Function in Health and Disease

07-089 Chemical Imaging of Living Cells in Real Time

07-096 Study of Epigenetic Mechanisms in a Model of Depression 
08-025 Combined PET/MRI Multimodality Imaging Probe

08-080 Tracer Development-Improving PET and MR Imaging

08-081 New MR Technology for Studies of Human Biology

\section{Detectors}

06-038

Growth and Characterization of CdZnTe Crystals for Improved Nuclear Radiation Detectors

07-073 Development of Room-temperature CdMnTe Gamma-ray Detectors

07-091 Development of a Planar Device Technology for Hyperpure Germanium X-ray Detectors.

08-062 A Novel Spintronic Room-Temperature High Purity Germanium X- and Gamma-Ray Spectrometer

\section{Other}

06-004 Detector Development for Very Long Baseline Neutrino Exp.

Development of Gadolinium-Loaded Liquid-Scintillators with Long-Term Chemical

06-030 Stability for a New High-Precision Measurement of the Neutrino Mixing Angle, Theta-13

06-056 Epigenetics: Methamphetamine (MAP)-Induced Brain Dysfunction and Methylation of DNA

06-060 Molecular Mechanism of Chromosomal Replication Initiation in Eukaryotic System

06-071 Development of a Cloud Condensation Nucleus Separator

07-004 Proof-of-Principle Laser System for ILC Positron Source

07-010 Design Optimization of a Reactor Neutrino Experiment

07-075 Developing a New Framework for Investigating Earth’s Climate and Climate Change

07-084 Investigations of Hygroscopic Growth and Phase Transitions of Atmospheric Particles by Noncontact Atomic Force Microscopy

07-090 Coherent Bragg Rod Analysis of High-Tc Superconducting Epitaxial Films

08-005 Development of the Deuteron EDM Proposal

Genomic DNA Methylation: The Epigenetic Response of Arabidopsis Thaliana

08-028 Genome to Long-term Elevated Atmospheric Temperature and CO2 in Global Warming

08-037 Ultrafast Electron Diffraction for Transient Structure and Phase Transition Studies at the NSLS SDL

08-051 Identification of Organic Aerosols and their Effects on Radiative Forcing 


\section{Department of Energy \\ Washington, DC 20585 \\ September 15, 2006}

Dr. Samuel Aronson

Director

Brookhaven National Laboratory

P.O. Box 5000

Upton, New York 11973-5000

THRU: Michael D. Holland

Manager

Brookhaven Site Office

Dear Dr. Aronson:

Based on the Brookhaven Site Office's recommendation, a review of the Brookhaven National Laboratory's FY 2007 laboratory directed research and development (LDRD) plan, and the Laboratory's ability to manage the LDRD program effectively, this letter provides approval of your FY 2007 LDRD plan and associated maximum funding level of $\$ 15.0$ million. Approval of the Brookhaven National Laboratory's funding level is contingent upon the Site Office's concurrence on each proposed LDRD project to ensure compliance with the requirements of DOE Order 413.2A and subsequent Departmental and Office of Science guidance documents.

We recognize how essential the LDRD program is to the health and vitality of the Laboratory, and how this program clearly enhances your ability to support the missions of the Department. As always the Laboratory needs to continue to conduct its LDRD program in full compliance
with Departmental policy.

If you have any questions, please contact John LaBarge on (202) 586-9747.

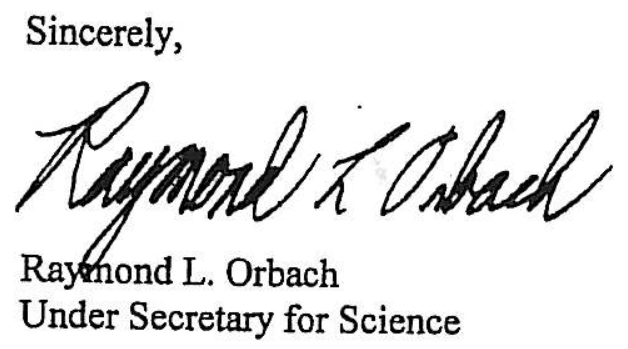

cc: N. Narain, Brookhaven Site Office

L. Newman, BNL

K. Fox, BNL 